\title{
NBSIR 87-3670
}

\section{A Review of Autoclaved Aerated Concrete Products}

Robert G. Mathey

Walter J. Rossiter, Jr.

U.S. DEPARTMENT OF COMMERCE

National Bureau of Standards

National Engineering Laboratory

Center for Building Technology

Gaithersburg, MD 20899

March 1988

$-Q C$

100

.456

\#87-3670

1988

c. 2

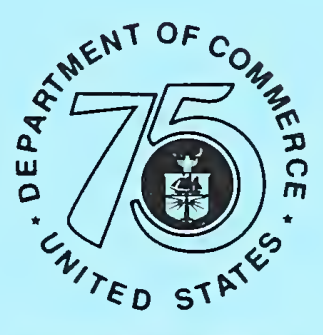

Stimulating America's Progress
1913-1988

U.S. Department of Energy Office of Conservation and Renewable Energy 1000 Independence Ave., SW Washington, DC 20585 



\section{A REVIEW OF AUTOCLAVED AERATED CONCRETE PRODUCTS}

Robert G. Mathey

Walter J. Rossiter, Jr.

U.S. DEPARTMENT OF COMMERCE

National Bureau of Standards

National Engineering Laboratory

Center for Building Technology

Gaithersburg, MD 20899

March 1988

Prepared for:

U.S. Department of Energy

Office of Conservation and Renewable Energy 1000 Independence Ave., SW

Washington, DC 20585

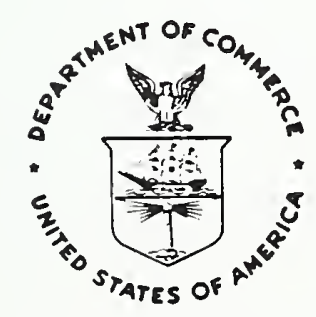

U.S. DEPARTMENT OF COMMERCE, C. William Verity, Secretary 

This report is a review of the properties and performance of autoclaved aerated concrete. The material has a relatively low thermal conductivity combined with loadbearing capacity for use in structural and non-structural applications. This feature may make its use attractive for energy-conserving applications. For this reason, the review was conducted at the request of the U.S. Department of Energy.

The review addressed an overview of the manufacturing process, uses of autoclaved aerated concrete in building constructions, properties, energy considerations, the availability of code-related documents, and standards. Uses include block and panel construction in both loadbearing and non-loadbearing applications for walls, floors, and roofs. Many properties are reviewed including density, fire resistance, moisture expansion and shrinkage, strength, structure, and thermal conductivity. With regard to energy considerations, the review points out that, for energyefficient applications under severe climatic conditions, the autoclaved aerated concrete unit alone may be insufficient to provide the targeted minimum value of thermal resistance. In these cases, autoclaved aerated concrete has to be used together with additional thermal insulation. In contrast, autoclaved aerated concrete alone may satisfy insulation needs in areas having mild climates.

Key words: aerated; autoclaved; cellular; concrete; insulating concrete; lightweight; manufacture; properties; review; standards; uses. 
1. INTRODUCTION . . . . . . . . . . . . . . . 1

1.1 Background . . . . . . . . . . . . . . 2

1.2 Objectives . . . . . . . . . . . . . 6

1.3 Scope of the study . . . . . . . . . . . . 6

2. MANUFACTURE OF AUTOCLAVED AERATED CONCRETE . . . . . . 8

3. USES OF AUTOCLAVED AERATED CONCRETE . . . . . . . . 12

3.1 Blocks . . . . . . . . . . . . . 13

3.2 Panels . . . . . . . . . . . . . . . . 14

3.3 Limitations . . . . . . . . . . . . . . . 16

3.4 Design Considerations . . . . . . . . . . . 17

3.4.1 The European Experience . . . . . . . 17

3.4.2 The U.S. Experience ........... 18

3.4.3 Moisture Considerations . . . . . . . 19

4. PROPERTIES OF AUTOCLAVED AERATED CONCRETE . • . . . . 22

4.1 Capillarity . . . . . . . . . . . . . . 23

4.2 Coefficient of Thermal Expansion ........ 23

4.3 Cracking . . . . . . . . . . . . . . 23

4.4 Creep ...................... 24

4.5 Density . . . . . . . . . . . . . . . . 25

4.6 Deterioration Resistance . . . . . . . . . 25

4.7 Fire Resistance . . . . . . . . . . . . . . 27

4.8 Frost Resistance . . . . . . . . . . . . . . 29

4.9 Moisture Expansion and Shrinkage . . . . . . . 31

4.10 Moisture Migration . . . . . . . . . . . . . 32

4.11 Permeability . . . . . . . . . . . . . 33

4.12 Shaping and Working . . . . . . . . . . . . 33

4.13 Specific Heat . . . . . . . . . . . . . 34

4.14 Solubility in Water . . . . . . . . . . . . 34

4.15 Sound Absorption . . . . . . . . . . . . . 34

4.16 Strength .................. 35

4.16.1 Compressive Strength . . . . . . . 36

4.16.2 Tensile Strength . . . . . . . . . . 37

4.16.3 Shear and Bond Strength . . . . . . . 38

4.16.4 Modulus of Elasticity ......... 40 
Page

4.17 structure . . . . . . . . . . . . . . . . 41

4.18 Temperature Resistance . . . . . . . . . . . . 43

4.19 Thermal Conductivity . . . . . . . . . . . 44

5. ENERGY CONSIDERATIONS . . . . . . . . . . . 46

6. STANDARDS AND RELATED DOCUMENTS .......... 50

7. SUMMARY . . . . . . . . . . . . . 51

8. ACKNOWLEDGMENTS . . . . . . . . . . . . 53

9. REFERENCES ................... 54 APPENDIX A . . . . . . . . . . . . . $A-1$ 
Figure 1. Countries Where Autoclaved Aerated Concrete is Used, as Described by Bave in 1983 [6]

Figure 2. Production of Autoclaved Aerated Concrete Products ........................... 63

Figure 3. Relationship Between the Cube Compressive Strength and the Density of Autoclaved Aerated Concrete [1]

Figure 4. Relationship Between the Compressive Strength and the Moisture Content of Autoclaved Aerated Concrete

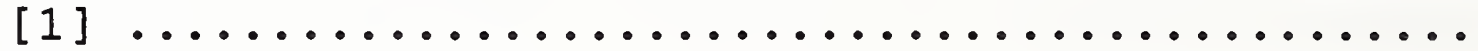

Figure 5. The Micro-Cellular Structure of Autoclaved Aerated

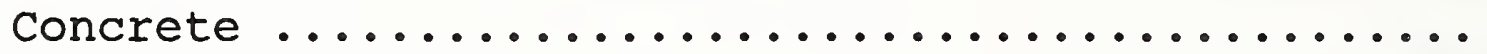

Figure 6. Example of Distribution of Pore Sizes in Autoclaved

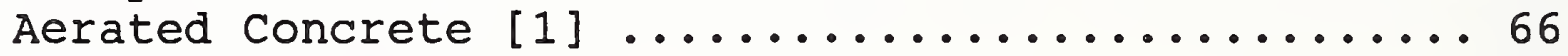

Figure 7. The Relationship Between the Thermal Conductivity and the Density of Dry Specimens of Autoclaved Aerated Concrete $[1] \ldots \ldots \ldots \ldots \ldots \ldots \ldots \ldots$

\section{LIST OF TABLES}

Table 1. Estimated 1987 Production of Autoclaved Aerated Concrete in Some Countries ...............6 67

Table 2. Examples of Values of Compressive Strength and

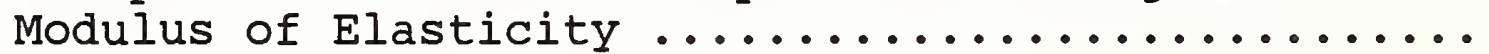




\section{INTRODUCTION}

Autoclaved aerated concrete $(A A C)$ is a construction material that is factory-made and available to the user in blocks and precast units for walls, floors, and roofs. Blocks for laying in mortar or glue are produced without any reinforcement $[1]^{1}$. It has gained widespread use in many areas of the world including Europe, South America, the Middle East, and the Far East. In brief, autoclaved aerated concrete is a porous lightweight concrete whose cellular structure is generally obtained through an in situ gas-producing chemical reaction of a sand and cement slurry. It generally contains no coarse material. Subsequent autoclaving of the material at high temperature and pressure imparts strength, dimensional stability, and other properties of the hardened final product. The autoclaved aerated concrete building material is obtained as the result of a reaction between the binder containing calcium oxide and a silica component cured in an autoclave [2], and a cellular structure producing ingredient. Autoclaved aerated concrete, is at times, referred to as "aerated concrete," "gasbeton," and "autoclaved lightweight concrete (ALC)."

Autoclaved aerated concrete is a type of cellular concrete. Another type, using preformed foam and cast in place, is commonly used in the United States for floor and roof fills. The important properties of autoclaved aerated concrete are present to a large degree in cellular concretes which have not been autoclaved [3].

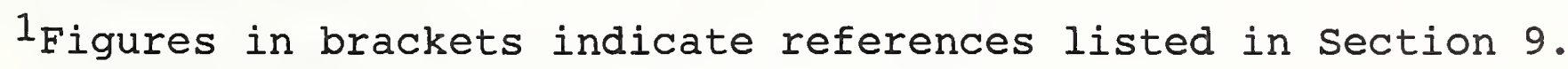


An often reported advantage [4-7] of autoclaved aerated concrete is the combination of relatively low thermal conductivity, and loadbearing capacity for use in structural applications. Other advantages include relatively low density, high strength-toweight ratio, nailability, fire resistance, good thermal resistance, and high sound insulation value $[8,9]$. Its low density permits use of large building units, which is a reported advantage in prefabrication.

The thermal conductivity properties offer potential to conserve energy by reducing building heating and cooling fuel consumption. The potential for energy conservation through the use of an alternative material of construction is of interest to the U.S. Department of Energy (DOE). Consequently, DOE requested the U.S. National Bureau of Standards (NBS) to undertake a study reviewing the properties and use of autoclaved aerated concrete. This report presents the results of the study. The study also provided an occasion to review opportunities for needed research.

\subsection{Background}

Autoclaved aerated concrete was first introduced commercially over 50 years ago $[6,10]$. Bessey $[4,11,12]$ has described its early development and use in some detail. Initial development of the products including autoclave curing occurred in the 1920 s in Scandanavia, with commercial use commencing in the early 1930s. However, little growth was experienced in commercial applications 
until the mid-1940s and the end of World War II. At this time, its use began to spread in some areas of Europe, in connection with post war building efforts. In subsequent years, expansion continued to many regions of the world. For example, the material was first used in the United Kingdom in about 1950 and by 1965 nine factories were operating under the direction of four different companies [4]. Use in the expansion years of the fifties did not result in U.S. production [13]. In the mid1960s, autoclaved aerated concrete represented a major portion of all structural materials used in some countries; for example, 2040 percent in USSR, Germany, Holland, and Sweden [4]. A 1987 estimate placed the amount of autoclaved aerated concrete used annually worldwide at about $8.1 \times 10^{8} \mathrm{ft}^{3}\left(23 \times 10^{6} \mathrm{~m}^{3}\right)^{2}$. Table 1 provides recent estimates of the annual production of the material for some countries. In 1987, autoclaved aerated concrete was produced in 35 countries $^{2}$.

Figure 1 depicts those countries where autoclaved aerated concrete was produced as of 1983 [6]. A notable feature in Figure 1 is the lack of use of autoclaved aerated concrete in Canada and the United States. Reasons for this lack of use have received little documentation in the archival literature. Most of the reasons for lack of use, uncovered during the present study, are anecdotal, coming from individuals who are familiar with the production and use of the material. In general, the

\footnotetext{
${ }^{2}$ Gunnar Bave, Siporex, personal communication.
} 
lack of use is attributed to factors associated with production costs and to tradition in the use of conventional building materials. For example, the costs of building a plant to manufacture hollow core concrete blocks may be 20 to 25 percent of the large initial investment to construct an autoclaved aerated concrete plant. In 1968, Bessey [12], writing in his paper on the worldwide development of autoclaved aerated concrete, indicated that the spread of the use of the material into the United States and Canada was marginal. He described the reasons for lack of growth as follows:

$$
\begin{aligned}
& \text { "The factors involved are many. Except in dense urban } \\
& \text { areas, timber still plays a large part in the construction } \\
& \text { industry in these countries. The concrete block } \\
& \text { industry is well organized and efficient, and the } \\
& \text { lightweight-aggregate block is highly competitive in } \\
& \text { cost and is generally of good quality. An aerated } \\
& \text { concrete plant must be of good size and have a market } \\
& \text { which will utilize it at nearly full capacity in order } \\
& \text { to be economic, for the capital costs and fixed } \\
& \text { overheads together constitute a high proportion of } \\
& \text { costs." }
\end{aligned}
$$

Bessey [11] also indicated that general factors affecting global development of autoclaved aerated concrete were partly climatic, partly economic, and partly psychological. Specific factors which he has discussed on this point include: the local building regulations or codes affecting building construction, availability 
of raw materials, climatic conditions, fuel and energy requirements, and costs due to production, transportation, erection and maintenance $[4,12]$.

It is interesting to note Bessey [12] indicated that, at the time he was writing (1968), two factories in Canada and one in the U.S. had achieved some minor degree of success. He did not state where these factories were located. The plants referred to by Bessey are not in operation today (Figure 1 ).

During the period 1955 to 1972 an autoclaved aerated concrete factory operated in Montreal, Canada. Some $54 \times 10^{4} \mathrm{ft}^{3}$

$\left(15 \times 10^{3} \mathrm{~m}^{3}\right)$ of its reinforced products were imported and used on a variety of building projects in the United States ${ }^{3}$.

Renewed interest in autoclaved aerated concrete use has recently occurred. For example, a news item indicated that a 42,000 $\mathrm{ft}^{2}$ $\left(3900 \mathrm{~m}^{2}\right.$ ) facility was completed in 1986 in Florida [14]. The building had autoclaved aerated concrete precast wall and roof panels which were imported from Sweden. The columns and beams consisted of conventional, precast, prestressed concrete. It was reported that the autoclaved aerated concrete components were imported at a relatively high shipping cost. In contrast, labor costs were reportedly saved due to the relative ease and reduction

${ }^{3}$ Samuel Aroni, University of California at Los Angeles, personal communication. 
of time associated with the installation of the lightweight autoclaved aerated concrete precast planks. The product was not covered by the building code and therefore a special permit was needed before the material could be used in Orange County, Florida [14].

\subsection{Objectives}

The objectives of this report are:

(1) to describe the process used in the manufacture of autoclaved aerated concrete,

(2) to present an overview on the use and properties of autoclaved aerated concrete products, and

(3) to provide a listing of standards and related documents developed for autoclaved aerated concrete.

\subsection{Scope of the study}

The present study was limited to reviewing existing information. No laboratory or field tests were conducted. The major sources of information were: (1) the archival chemical and engineering literature; (2) worldwide building research organizations in Canada and Europe (including England, Denmark, France, Norway, and Sweden); (3) discussions with researchers knowledgeable with autoclaved aerated concrete technology; and (4) literature from and discussions with representatives of manufacturers of autoclaved aerated concrete products. 
As a construction material which has achieved worldwide use, the body of technical information on autoclaved aerated concrete including research reports, standards, design criteria, codes of practice, and related documents is extensive. A bibliography of archival literature having 492 citations was published in 1983 [15]. The bibliography is included in a Proceedings of an International Symposium entitled "Autoclaved Aerated Concrete, Moisture and Properties" [16]. In 1954, Valore [13,17] gave a review of methods of preparation and physical properties of moist-cured and high-pressure steam-cured cellular concretes, ranging in density from $10-1001 \mathrm{bm} / \mathrm{ft}^{3}\left(160-1600 \mathrm{~kg} / \mathrm{m}^{3}\right)$. The review covered three decades beginning in the mid-1920s.

It is noted that at least one process for aerating and autoclaving a lightweight aggregate structural concrete has been described in the literature [18]. This lightweight aggregate concrete has a higher density and greater strength than autoclaved aerated concrete. The scope of the present study precluded a review of this material and other lightweight aggregate concretes. 


\section{MANUFACTURE OF AUTOCLAVED AERATED CONCRETE}

The manufacture of autoclaved aerated concrete products has been described in the archival literature [1,19-24] and in manufacturers' publications. Although the processes used by different manufacturers are proprietary and have differences between them, the overall procedures of each are considered comparable. The manufacture of autoclaved aerated concrete products is carried out in factories where quality control measures can be implemented regarding materials and handling, as well as the individual steps involved in the overall process.

Production is a continuous process which may be envisioned as having four stages, as shown in Figure 2. The four stages are depicted as: (1) raw materials, (2) molding and cutting, (3) autoclaving, and (4) stocking and shipping.

Raw Materials. The major raw materials are, in many processes, sand and portland cement. In place of sand, other siliceous materials such as sandstone, shale ash, fly ash, and mixtures are often used. For example, fly ash has been substituted for ground sand to the extent of 100 percent 4 . Lime or cement/lime mixtures are at times used instead of portland cement. The raw materials are used as fine powders which are normally obtained through grinding. Grinding may be done either through a wet or dry procedure.

${ }^{4}$ Poul Nerenst, $\mathrm{H}+\mathrm{H}$ Industri, personal communication. 
Accurately proportioned quantities of the raw materials form the mix. In many cases, a slurry of the siliceous component is made in heated water whose temperature is controlled. The slurry is placed in a mixer into which the cement and/or lime are added. Admixtures such as surfactants and compounds for controlling the rate of cure may also be added.

Generation of the cellular structure is normally done through the addition of aluminum powder as the mixing procedure is ending. The aluminum powder in the alkaline medium (due to the cement or lime) produces hydrogen gas which, in turn, generates the cells. The addition of the aluminum powder is controlled so that gassing does not begin during mixing, but during the molding stage. For example, one control technique uses aluminum powder surfaced with a layer to delay the reaction with the alkalies. Other methods for producing the cellular structure are the introduction of a preformed foam into the mix, or the incorporation of air by whipping [1].

Molding and cutting. The mixture (from stage 1 ) is put into steel molds where the production of hydrogen begins and the mass expands, creating the aerated cellular structure. The expanded mass is allowed to set to a soft cake under controlled temperature and humidity conditions. The reaction time for expansion and setting is 30 minutes to a few hours (about 1 
to 4) depending upon the raw materials. After setting, the cake is cut into the dimensions of the final product (e.g., block or panel units) using highly strung wires (piano wires) or multiple circular saws.

If the final product is to be used for structural applications, steel reinforcement is placed in the mold before casting the autoclaved aerated concrete. The factory procedure allows accurate placement of the reinforcement in the molds so that the set cake may be cut into the intended dimensions without damage. The steel reinforcement is protected from corrosion, normally by coating [25]. For example, one process uses a coating based on portland cement, latex, and finely ground sand. Another process uses a bituminous compound.

Autoclaving. The third stage of the process is the autoclaving whereby the aerated concrete cures to its final strength and dimensions. Autoclaving changes the physical-chemical nature of the hydrated cement materials and produces a material with lower drying shrinkage [26]. The conditions for autoclaving vary somewhat for different proprietary products. In general, the temperature is about $356^{\circ} \mathrm{F}$ $\left(180^{\circ} \mathrm{C}\right)$ at a pressure of about $10-12$ atmospheres $(1.0$ 1.2 $\mathrm{MPa})$. The time varies depending on the size and density of the products, and may range from about 10 to 20 hours. Storage of the uncured cake, even through moist and warm, 
for more than 2 or 3 days prior to autoclaving may be detrimental [27].

Stocking and Shipping. After the cured units are removed from the autoclave, quality assurance tests are normally conducted. Also, if desired, additional shaping through milling or related means may be carried out and a surface finish may also be applied. After autoclaving and cooling the units are ready for use without storage. If not needed immediately after production, the units are stored at the factory site and then delivered to the job site for installation. 


\section{USES OF AUTOCLAVED AERATED CONCRETE}

The factory-made autoclaved aerated concrete units delivered to the job site are of different types and have many uses. The types of units most commonly produced are blocks and precast panels for floors, walls, and roofs. Less often, complete modular room units are produced in the factory from wall, floor, and roof panels. The blocks and panels are used in both loadbearing and non-loadbearing constructions for both residential and commercial/industrial buildings. As a consequence, autoclaved aerated units are found in single and multi-story constructions oriented both horizontally and vertically. Larger units are reinforced with steel bars or welded mats to resist damage due to superimposed loads and from transportation and handling [8]. It also has been used as an extra layer of insulation for other components of the building envelope [28].

Blocks and panel units are manufactured to very close dimensional tolerances [29]. For example, the French Standard (NF P 14-306) for autoclaved aerated concrete blocks for walls requires that the dimensional tolerance of the length be $\pm 0.1 \mathrm{in} .( \pm 3 \mathrm{~mm})$ for a minimum block length of $30 \mathrm{in.}(760 \mathrm{~mm})$. Close dimensional tolerence is important with regard to modular construction to assure that individual units fit together properly. Consequently, the sizes of the factory-produced units are generally based on a modular system of standard products. One reference points out that the modular construction concept provides for simple and 
fast construction, comparatively low costs, and good architectural possibilities [30]. Any deviation from the standard sizes of units could lead to extra costs. As an example of construction efficiency, Nettleton [31] has indicated that a team of eight persons erected, on a prepared foundation, all wall, floor, and roof units for a block of 12 flats in 18 working days. The units were basically $2 \mathrm{ft}(0.6 \mathrm{~m})$ wide and of varying lengths up to 16 ft $(5 \mathrm{~m})$.

Construction time is shortened and building costs reduced by increasing the size of panels [32]. The use of large panels results in a reduction in the number of joints and less manual labor is involved on site.

\subsection{Blocks}

A general application of autoclaved aerated concrete has been in the form of masonry block. Blocks are available in standard sizes and generally do not contain reinforcement [21]. They have been widely used for side cladding and as "in filling" for external walls, as well as for external and internal loadbearing walls in low and multi-story construction. In early constructions, blocks were laid using mortar joints. In later uses, construction techniques expanded to include use of thin glue joints $10.08-$ 0.1 in. or $2-3 \mathrm{~mm}$ ) in place of mortar joints [33]. This technique was possible because of the dimensional precision of the blocks. 
Since autoclaved aerated concrete blocks are of relatively low weight, they are often somewhat larger than concrete masonry units manufactured in the United States. Due to the cutting process during manufacture, the blocks may have an architectural surface (often referred to as a wire cut or scratched surface) [34]. This surface allows the use of the blocks without a decorative rendering or parging. External surfaces of autoclaved aerated concrete should be protected from exposure to water.

\subsection{Panels}

As previously mentioned, autoclaved aerated concrete panels are manufactured in various sizes and are used in vertical and horizontal applications in building construction. Vertical wall panels are available in "story-height" increments, and have been used in loadbearing applications up to three or four stories high $[1,10]$. Wall panels are also laid up horizontally. These panels normally do not carry any load other than their own dead weight.

Another common use of autoclaved aerated concrete is for roof and floor slabs. These panels have span lengths of $20-25 \mathrm{ft}(6-$ $7.6 \mathrm{~m})[10]$. During erection, the slabs are commonly placed, direct from a truck, on loadbearing walls or a structural frame without use of a mortar bed. Bituminous roofing membranes have been applied directly to assembled roof panels [1,34]. Regarding this practice, it has been reported that the autoclaved aerated concrete panels fit closely together and serve as thermal 
insulation [34]. The design of the roof should consider movement between adjacent panels to prevent splitting of the roofing membrane $[1,35]$. In the conduct of the study, reports addressing the performance of roofing membranes applied directly to autoclaved aerated concrete panels were not found in the literature.

Autoclaved aerated concrete panels are also accepted in several countries for basement walls below ground level [1]. For this application, precautions must be taken to allow moisture present during manufacturing to dry from the walls. One method involves the application of impermeable protection on the outside of the wall below ground level.

In concluding the remarks on autoclaved aerated concrete in panel construction, it is pointed out that this practice in the 1960s involved the use of large-sized panels. For example, in 1965, Bave [36] described European panels having widths up to $5 \mathrm{ft}$ $(1.5 \mathrm{~m})$ and lengths up to $26 \mathrm{ft}(8 \mathrm{~m})$. With thickness up to 10 in. $(25 \mathrm{~cm})$, large panels might weigh about 2 tons $(1800 \mathrm{~kg})$. In Russia, where considerable autoclaved aerated concrete is used for both industrial and residential buildings, the panels were even larger, with spans up to $40 \mathrm{ft}(12 \mathrm{~m})$ [37]. However, as far back as the late $60 \mathrm{~s}$, it was recognized that excessively large panels could have a serious drawback, with cracking sometimes occurring during manufacture or in-service [32]. Recently, in 1980, Bave [38] noted that the trend of using large panels, as 
occurred of the sixties seems to be broken, at least in the countries in Western Europe. The demand for large panels decreased due to architectural preferences and cost considerations. At present, the use of large panels is mainly in industrial constructions.

\subsection{Limitations}

Although autoclaved aerated concrete has been a long-accepted construction material, the literature is not without reference to limitations in its use. For example, used in modular units, any deviation from standard sizes could lead to extra costs [30].

Some limitations have been reported by Tietz [39], including: the material chips easily; the face tends to get damaged easily, e.g., from scaffolding; dowels are required between units; the external face is hygroscopic and needs a protective coating which can breathe and should be protected from standing water, bottom units should be protected from splash back; units absorb enormous quantities of paint; anchorage of units needs careful planning to prevent pullout, especially for dynamic loads; the face is weak and any tough surface may pull away due to the interface pulling off the parent material. Finally, it should be mentioned that caution should be exercised in transporting and handling the units to avoid damage $[30,40]$. 


\subsection{Design Considerations}

\subsubsection{The European Experience}

A manual entitled, "Autoclaved Aerated Concrete-Design and Technology" was produced by the Euro-International Committee for Concrete (CEB) [1]. As indicated in the Preface, the manual is "a source of information on the technology of this material and methods of construction associated with it, but it is not directly referable to the Code," (i.e., the CEB-International Federation for Prestressing (FIP) Model Code for Concrete). The manual addresses the manufacture and properties of aerated concrete, design considerations, and economic considerations. Many typical construction details and application photographs are presented.

The manual indicates that codes and practices in some countries give advice on calculation methods for allowable stresses in autoclaved aerated concrete structural members [1]. It also advises to check the design principles for autoclaved aerated concrete structural units with full-scale tests. Results of testing of autoclaved aerated concrete under dynamic repeated loads indicate that the fields of application of this material must be chosen carefully [41].

Briesemann [42] in his paper concerning criteria for the design of structural elements of autoclaved aerated concrete indicated that knowledge relating to their design is not yet complete. He 
stated that structural elements of this material have been used in buildings for over 50 years and they have proved to be satisfactory in practice. With regard to reinforced structural elements, there is a lack of knowledge about the effects of loads applied to only part of the surface of a component and about the design for simultaneous loading by shear and torsional forces. Briesemann stated further that known design rules have not been verified by scientific experiments like those for reinforced concrete structures and may allow for excessively large safety coefficients. This applies, for example, to the coefficient of creep (ratio of the creep deformation to the elastic deformation) of masonry constructions of autoclaved aerated concrete blocks [42].

\subsubsection{The U.S. Experience}

As previously noted, autoclaved aerated concrete precast units are not presently produced in the United States and Canada. The American Concrete Institute (ACI) publication entitled, "Guide for Low Density Precast concrete Floor, Roof, and Wall Units," outlines practices of design and fabrication of low density, 50 $1 \mathrm{bm} / \mathrm{ft}^{3}\left(800 \mathrm{~kg} / \mathrm{m}^{3}\right)$ and under, precast reinforced concrete floor, roof, and wall units which will result in members of adequate load capacity, durability, appearance, and over-all serviceability for the function intended [43]. Both cellular and low density aggregate precast concrete are included in the guide. Units covered by the guide should be protected from the free entry of water. The guide gives allowable design stresses for concrete 
and reinforcement and provisions for anchorage of tensile steel reinforcement. Other provisions are given such as corrosion protection for reinforcement, permissible span deflections, and test of individual flexural units. The compressive strength of the low density concrete used in precast units should have a minimum compressive strength of $300 \mathrm{lbf} / \mathrm{in}^{2}(2.1 \mathrm{MPa})$. The design allowable stresses in the concrete should conform to the requirements of ACI 318 [44], except for shear stress permitted in an unreinforced web and the compressive stress allowed in low density precast concrete load bearing walls. Dunn [26] discussed some provisions of the ACI guide [43] with regard to precast autoclaved aerated concrete units and he also discussed some physical properties of these units.

The Council of American Building Officials (CABO) and the U.S. Department of Housing and Urban Development (HUD) have issued a report [45] and a Materials Release [46], respectively, for the use of a proprietary autoclaved aerated concrete. The CABO report defines allowable uses for roof, floor, curtain wall, and partition panels and blocks. The HUD Materials Release is for a thin-joint block wall system.

\subsubsection{Moisture Considerations}

Autoclaved aerated concrete contains moisture from the manufacturing process. The moisture content at the time of delivery to the building site may be 20 - 35 percent by weight (10 - 18 percent 
by volume) [1]. The moisture dries out gradually in normally one to two years and reaches equilibrium in external constructions of about 4 - 6 percent by weight ( $2-3$ percent by volume) [1]. Moisture may also accumulate in the material during construction and after the building is completed (e.g., from rain and condensation). It is necessary to assure that the design provides for drying out of the initial moisture as well as maintaining low moisture content in the building under service conditions. One literature reference indicated that, if the inside humidity is 60 percent or less, the use of autoclaved aerated concrete is practically unlimited [22]. Higher humidity requires measures to limit vapor diffusion. In general, autoclaved aerated concrete in equilibrium with a normal environment ( 65 percent R.H. and $68^{\circ} \mathrm{F}$ or $20^{\circ} \mathrm{C}$ ) tends to have a moisture content of about 3 percent by volume [47].

As indicated in the ACI Guide 515.1R-79, concrete masonry walls above grade should normally be painted on the exterior for dampproofing purposes [48]. Because of the higher porosity and moisture absorption of autoclaved aerated concrete, as compared to dense concrete, a surface treatment should be considered for exterior surfaces of autoclaved aerated concrete masonry and wall panels. The external treatments that are currently used are mortar for masonry walls and paints for wall panels [1]. The paint used should be nearly impermeable to water but should have some permeability to water vapor so that, if moisture should 
become trapped or condensed within the wall, it can slowly escape to the exterior. Protections for masonry have included one to three coats of mortar (not exceeding $0.8 \mathrm{in}$. or $20 \mathrm{~mm}$ ) for external application, and for internal use, a thin application of resin or gypsum plaster, lime mortar, or paint $[1,49]$.

For decorative purposes, ceramic tiles, colored sand or granite, marble chips, broken glass, and other materials can be used on wall panels [37]. External walls may also have a prefinished surface $[50]$. 


\section{PROPERTIES OF AUTOCLAVED AERATED CONCRETE}

The physical and mechanical properties of autoclaved aerated concrete may be made to vary over a considerable range, depending on the quantities of the raw materials used, the mix design, and curing conditions $[17,18]$. It is important to note that many properties of cellular concrete can be given as functions of bulk density and thickness $[24,51]$. This section of the report presents a brief summary of the most often reported properties of autoclaved aerated concrete. A summary table of property values has not been provided because of their wide variation between products due to factors such as density, structure, thickness, moisture, raw materials, and production conditions. The properties summarized herein are based essentially on the list given in the CEB Manual [1]:

- Capillarity

- Coefficient of Thermal Expansion

- Cracking

- Creep

- Density

- Deterioration Resistance

- Fire Resistance

- Frost Resistance

- Moisture Expansion and Shrinkage

- Moisture Migration

- Permeability

- Shaping and Working 
- Specific Heat

- Solubility in water

- Sound Absorption

- Strength (compressive, tensile, shear and bond, modulus of elasticity)

- Structure

- Temperature Resistance

- Thermal Conductivity

\subsection{Capillarity}

Capilarity is important for wetting and drying out the materials. The capillary suction is slow in aerated concrete compared with some other porous materials such as clay bricks [1]. Capillary suction takes place almost exclusively through the micropores in the cell walls and is negligible for the macropores [1].

\subsection{Coefficient of Thermal Expansion}

The coefficient of linear thermal expansion for autoclaved aerated concrete is $4.5 \times 10^{-6}$ per ${ }^{\circ} \mathrm{F}\left(8 \times 10^{-6}\right.$ per $\left.{ }^{\circ} \mathrm{C}\right)$ compared to $6.8 \times 10^{-6}$ per ${ }^{\circ} \mathrm{F}\left(12 \times 10^{-6}\right.$ per $\left.{ }^{\circ} \mathrm{C}\right)$ for mild steel reinforcement $[6,21,28]$. Dense concrete and steel have about the same value of coefficient of linear thermal expansion.

\subsection{Cracking}

One of the major concerns with autoclaved aerated concrete is that of cracking, both externally and internally [28]. Cracking 
may be caused by shrinkage, creep, temperature, moisture effects, or by deformation and settlement of foundations. It is not always possible to separate the causes and effects of cracking. The repair of cracks in occupied houses and apartments can be difficult and expensive. In a study by Cividini [52], it was reported that prestress of autoclaved aerated concrete slabs, due to differential drying and cooling after autoclaving, may in some cases increase crack resistance to such an extent that the slab cross-section may remain without cracks during its service life.

\subsection{Creep}

For all autoclaved materials, creep is low in relation to the elastic deformation [18]. Factors affecting creep of autoclaved aerated concrete are stress level, moisture content, ambient temperature and relative humidity. A creep coefficient (creep strain divided by the momentary deformation) is indicated as 0.8 to 1.2 for autoclaved aerated concrete having a density of $31 \mathrm{lbm} / \mathrm{ft}^{3}$ $\left(500 \mathrm{~kg} / \mathrm{m}^{3}\right)$ [1]. According to Kruml [53], factors influencing the quantitative value of creep have not been sufficiently defined and evaluated. For this reason, he noted that the creep coefficient often differs in the literature. Also, creep is indicated to be proportional to the applied stress up to a stress of approximately 50 percent of the strength of the autoclaved aerated concrete [1].

In creep studies by Nielson [54] using unreinforced beams, he reported creep coefficients, after one year for dry material at 
$43 \%$ R.H., that ranged from 0.2 to 0.3 . For water-saturated material, the creep coefficients ranged from 0.2 to 0.6 . These values are somewhat less than those found for normal concrete.

In a study by Houst, Alou, and Wittmann [55], larger creep deformations for moist specimens were reported than for dry ones.

\subsection{Density}

Density of autoclaved aerated concrete generally refers to ovendry material. At the time that the material is delivered to the building site, the practical density is higher because of the moisture content and presence of any reinforcement. The density of autoclaved aerated concrete is normally reported in the range of $19-62 \mathrm{lbm} / \mathrm{ft}^{3}\left(300-1000 \mathrm{~kg} / \mathrm{m}^{3}\right)$, with $31 \mathrm{lbm} / \mathrm{ft}^{3}$

$\left(500 \mathrm{~kg} / \mathrm{m}^{3}\right)$ or more being the most common density for loadbearing products and reinforced flexural members $[1,56]$. Bave [38] reported in 1980 that a density of $22 \mathrm{lbm} / \mathrm{ft}^{3}\left(350 \mathrm{~kg} / \mathrm{m}^{3}\right)$ is now used for structural units of autoclaved aerated concrete such as loadbearing walls, floors, and roofs. The dry density of the solid material (without pores or air cells) is $150 \mathrm{lbm} / \mathrm{ft}^{3}$ (2500 $\left.\mathrm{kg} / \mathrm{m}^{3}\right)$.

\subsection{Deterioration Resistance}

Autoclaved aerated concrete, because of its porosity and relatively low alkalinity $(\mathrm{pH}=9-10.5)$, does not provide the same corrosion protection of reinforcement as that provided by dense concrete [1]. 
Thus, it is recommended that reinforcement should be protected against corrosion by adequate surface treatment [1]. In areas of relative humidity less than 50 percent at equilibrium moisture content, corrosion of reinforcement is reported likely to be negligible [1].

There also may be a risk of corrosion of nails and steel anchors because of the initial moisture content of the material, or moisture from condensation or rain penetration [1]. Acids in the form of liquid and gases penetrate aerated concrete more easily than dense concrete and their deteriorating effect is more rapid than for dense concrete. Autoclaved aerated concrete should therefore be protected from acidic liquids or fumes. The porous structure of autoclaved aerated concrete allows air to penetrate the material readily and, depending on the availability of carbon dioxide and atmospheric humidity, a decrease in alkalinity of the material occurs [25]. During autoclave treatment in high pressure steam, a reaction takes place between the calcium hydroxide and finely ground silicate aggregate components to form calcium silicate hydrates. Because of this reaction, the lime availability is greatly reduced and the calcium hydroxide content of the concrete is lowered. Thus, it was found that 10 in.

$(24 \mathrm{~cm})$ thick autoclaved aerated concrete members had been carbonated throughout after only two years of service [25]. The CEB Manual [1] indicates that carbonation of autoclaved aerated concrete is generally not of concern if the carbon dioxide content of the air 
is as normally expected ( 0.03 percent). For carbon dioxide concentrations above about 0.2 percent, carbonation of the calcium silicate hydrate of fresh, moist autoclaved aerated concrete can proceed rapidly and may lead to shrinkage cracking [1]. Manufacturer's recommendations should be followed if autoclaved aerated concrete is to be exposed to carbon dioxide concentration above about 0.2 percent.

One literature reference has noted that autoclaved aerated concrete is resistant to insects, termites, and fungi [21].

\subsection{Fire Resistance}

Autoclaved aerated concrete is non-combustible [1]. Because of its low thermal conductivity, heat migration takes place at a much lower rate than in dense concrete. Consequently, the fire ratings for autoclaved aerated concrete units issued in some countries in Europe indicate that this material provides for very good fire resistance compared to other building materials $[1,28]$. One reference [21] indicated that, for the same thickness, the use of cellular concrete in place of normal concrete has been reported to increase the fire resistance by 30 to 40 percent. In comparison, another reference [8] stated that a 4.0 in. $(10 \mathrm{~cm})$ thick aerated concrete slab gives fire resistance of 2 hours against one hour for an $4.4 \mathrm{in.}(11 \mathrm{~cm})$ thick brick wall or a 4.0 in. $(10 \mathrm{~cm})$ thick normal concrete slab. As another example of the fire rating of autoclaved aerated concrete, the Fire offices 
Committee in the U.K. recognizes that a 6.0 in. $(15 \mathrm{~cm})$ thick loadbearing fire break of the material will give six hours fire resistance [3]. The fire rating of loadbearing roof and floor flexural units depends upon density and the thickness of the cover of the reinforcement. Autoclaved aerated concrete may be used as a cladding to protect other materials such as steel members or to increase the fire rating of normal concrete walls $[1]$.

In the early 1960s, the U.S. National Bureau of Standards conducted fire tests of lightweight, cellular precast concrete (reportedly of the in situ gas-forming type) panels for floors and roofs [57]. It was found that fire endurances were up to 2 hours for 6 in. $(15 \mathrm{~cm})$ thick slabs tested under load, and up to 4 hours for other slabs not loaded. It was also found that, within the narrow density range of $35-50 \mathrm{lbm} / \mathrm{ft}^{3}(560-800$ $\mathrm{kg} / \mathrm{m}^{3}$ ), slabs made of higher density cellular concrete provided longer fire endurance than those of lower density, both in terms of heat transfer through the slab and in terms of continued structural stability. The use of greater cover for the reinforcing bars, in the range of $3 / 4$ to $1-1 / 4$ in. (19 to $32 \mathrm{~mm}$ ), even without increasing the total thickness of the cellular concrete, will result in longer fire endurance. 


\subsection{Frost Resistance}

The extensive use of aerated concrete in countries with cold climates indicates that the material has resistance to frost. Nevertheless, a risk of frost damage exists if the moisture content in any part of the construction unit exceeds the critical moisture content of the autoclaved aerated concrete. The critical moisture content can be considered as the moisture content of the material at which, upon freezing and thawing, a loss in strength properties or damage occurs. The critical moisture is, for example, about 40 percent by volume for aerated concrete manufactured in Sweden with a density of $31 \mathrm{lbm} / \mathrm{ft}^{3}$ $\left(500 \mathrm{~kg} / \mathrm{m}^{3}\right)$ [1]. However, the moisture content is usually highest during construction, rarely exceeding 15 - 20 percent by volume, before drying out takes place [1]. Under extreme conditions, higher moisture contents may occur close to the surface of the unit which increases the risk of frost damage. Edlind [28] reported that heavier autoclaved aerated concretes are satisfactory with regard to frost resistance but at densities below about $31 \mathrm{lbm} / \mathrm{ft}^{3}\left(500 \mathrm{~kg} / \mathrm{m}^{3}\right)$ liability to frost damage increases.

From tests of 30 cycles of freezing for 5 hours and thawing for 3 hours, Purins [58] concluded that the critical moisture content was between 50 - 70 percent by volume and is dependent on the bulk density. Critical moisture content was 50 percent by volume for density of $25 \mathrm{lbm} / \mathrm{ft}^{3}\left(400 \mathrm{~kg} / \mathrm{m}^{3}\right)$ and $65-70$ percent by volume for 
density of $40 \mathrm{lbm} / \mathrm{ft}^{3}\left(650 \mathrm{~kg} / \mathrm{m}^{3}\right)$. Tensile strength after the test.s decreased considerably, from 60 - 70 lbf/in $2(0.41-0.48 \mathrm{MPa})$ to 4 - $20 \mathrm{lbf} / \mathrm{in}^{2}(0.03-0.14 \mathrm{MPa})$. This decrease was attributed to internal damage occurring during the test, although reportably not visible from the outside [58].

In a similar study, Roulet [59] reported on the resistance to frost action of three different densities of autoclaved aerated concrete. The densities were 19, 25, and $31 \mathrm{lbm} / \mathrm{ft}^{3}(300,400$, and $\left.500 \mathrm{~kg} / \mathrm{m}^{3}\right)$. The frost expansion upon cooling to $-4^{\circ} \mathrm{F}\left(-20^{\circ} \mathrm{C}\right)$ and their length during thawing was measured. With dry samples, there was linear thermal expansion. For samples with low water content (degree of saturation of 20 - 40 percent by weight), they exhibited contraction on freezing, and after thawing no significant permanent expansion was measurable. Specimens having a critical water content (60 - 70 percent by weight), which is low compared to the total porosity or the zero pressure capillary water content, exhibited a large expansion while freezing to about $-4^{\circ} \mathrm{F}$ $\left(-20^{\circ} \mathrm{C}\right)$. After thawing, the sample with critical water content showed a permanent expansion. If the samples were nearly saturated with water, they became very brittle after one freezethaw cycle. Roulet [59] also reported that samples with a high degree of saturation upon freezing became brittle and cracked. However, scanning electron micrographs gave no evidence of a structure change due to freezing. 
In a related study, tests carried out on factors such as loss of weight on freezing, tensile strength after freezing, and changes in length and volume after repeated cycles indicated that the critical degree of saturation was about $35-40$ percent of pore saturation [60]. Pore saturation denotes that the total pore volume is filled with moisture. The dynamic modulus of elasticity was determined for each cycle for samples in the thawed condition. Damage occurred at a degree of pore saturation of $38-45$ percent [60]. However, a measure of the critical degree of moisture was also obtained by studying the moisture-dependent deformation of samples. It varied to some extent due to the quality of the material and seemed to be in the range of $50-60$ percent [60].

\subsection{Moisture Expansion and Shrinkage}

Autoclaved aerated concrete is similar to dense concrete in that it expands on wetting and shrinks on drying [28]. Drying shrinkage varies with density and method of manufacture. Values of drying shrinkage range from 0.1 to 0.5 percent when measured from saturated condition to a condition of equilibrium at 45 percent R.H. [28]. The low drying shrinkage of an autoclaved product as compared to that for air-cured cellular concrete, has been attributed to chemical reactions that take place during autoclaving [21].

The test results for shrinkage may vary considerably with different materials and methods of tests. In practice, the 
shrinkage between delivery moisture content and equilibrium moisture content is of interest [1]. Excessive drying below equilibrium at 43 percent relative humidity results in an increase in shrinkage of the material. An example of shrinkage was given for materials where the moisture content was reduced from about 75 percent to 3 percent by mass. The materials were tested from water-saturated condition to equilibrium at 43 percent R.H. and $68^{\circ} \mathrm{F}\left(20^{\circ} \mathrm{C}\right)$. The shrinkage for this case was 0.03 percent [1]. The density of the materials was not reported.

\subsection{Moisture Migration}

Autoclaved aerated concrete, due to its higher porosity, has higher moisture absorption than dense concrete. Moisture may migrate through capillarity, or through diffusion or both. For normal moisture content conditions, the moisture migration is mainly by diffusion and with increasing moisture content, it is due more to capillarity [1]. Moisture migration is due almost entirely to capillarity when the moisture content is above 40 percent by mass (20 percent by volume). The moisture migration is also influenced by the pore structure, the dimensions of the unit, the thermal conductivity of the material, temperature, vapor pressure, and movements of the air to which the surfaces of the construction units are exposed. 


\subsection{Permeability}

The permeability of autoclaved aerated concrete to air varies with the moisture content of the material. It decreases with an increase in moisture content in the pores [6]. Nevertheless, the CEB Manual [1] has indicated that the permeability of dry material at normal pressure differences, such as caused by wind, is very low and may be considered negligible. It is noted that significant penetration can take place through improperly formed joints and other connections in the building.

The water vapor permeability by diffusion also decreases with an increase in the moisture content of the material. The diffusion factor of aerated concrete (ratio between the diffusion of water vapor through a layer of air to that through a layer of material of the same thickness) has been determined to be $5-7$ under air dry conditions for material having a density of $31-38 \mathrm{lbm} / \mathrm{ft}^{3}$ $\left(500-600 \mathrm{~kg} / \mathrm{m}^{3}\right)[1]$.

\subsection{Shaping and working}

During construction, autoclaved aerated concrete can be easily cut, nailed, drilled, milled, or shaped to accomodate building needs such as utilities, or other construction requirements $[1,28,61]$. In most cases, ordinary woodworking tools can be used. Reinforced flexural members should not be cut on the construction site without authorization of the manufacture since anchorage of reinforcement may be affected [1] 
Attachment of other buildings units, materials, or accessories to autoclaved aerated concrete is more critical than those in denser materials such as brick or normal concrete, since ultimate failure loads (pullout) are lower [62].

\subsection{Specific Heat}

Specific heat of a material is the heat required to raise the temperature of unit mass of the material one degree. It is a measure of the capacity of a material to store heat. For autoclaved aerated concrete the value of specific heat is about $0.24-0.26 \mathrm{Btu} / \mathrm{bbm}^{\circ} \mathrm{F}\left(1.0-1.1 \mathrm{~kJ} / \mathrm{kg}^{\circ} \mathrm{C}\right)$ for material of normal moisture content ( 2 - 3 percent by volume or $4-6$ percent by weight) [1].

\subsection{Solubility in water}

The strength-related components of autoclaved aerated concrete have only very low solubilities in water. However, depending on the raw material and mix proportions the product may contain small quantities of soluble salts which, under certain climatic conditions such as those resulting in slow evaporation, may crystallize on the surface to form efflorescence [1].

\subsection{Sound Absorption}

Autoclaved aerated concrete is considered to provide good sound insulation, having sound absorption properties somewhat better than that for smooth dense concrete $[1,21,28]$. The sound 
absorption coefficient of untreated autoclaved aerated concrete was reported to be $0.00,0.15,0.25,0.20,0.20$, and 0.20 for frequencies $\left(\mathrm{H}_{\mathrm{Z}}\right)$ of $125,250,500,1000,2000$, and 4000 respectively

[1]. If the aerated concrete is painted or coated, its sound insulation effectiveness is reduced. In general, for solid construction, sound transmission depends on the mass of the structure. Cavity wall construction gives greater sound reduction than solid construction for the same total mass [20].

\subsection{Strength}

Considerable data have been generated regarding the strength of autoclaved aerated concrete including compression, tension, shear and bond strength, and modulus of elasticity. Strength tends to increase with an increase in density, while thermal resistance tends to increase with a decrease in density [28]. According to Shrivastava [21], there is a straight line relationship between strength and density. Grimer and Brewer [63] tested four aerated concretes of varying density, $33-43 \mathrm{lbm} / \mathrm{ft}^{3}\left(530-690 \mathrm{~kg} / \mathrm{m}^{3}\right)$, and found that there was a slight systematic increase in strength with depth. The strength increases were accompanied by increase in specific gravity. The moisture content of autoclaved aerated concrete also has an influence on its strength. Svanholm [64] reported that strength decreases with an increase in moisture content. This was found for compressive and tensile strength and modulus of elasticity. 


\subsubsection{Compressive Strength}

The compressive strength of autoclaved aerated concrete increases with an increase in density $[1,8]$. The average value of compressive strength measured using cubes for a dry density of $25 \mathrm{lbm} / \mathrm{ft}^{3}$ $\left(400 \mathrm{~kg} / \mathrm{m}^{3}\right.$ ) was reported to be about $290 \mathrm{lbf} / \mathrm{in}^{2}$ ( $2 \mathrm{MPa}$ ), and for a dry density of $44 \mathrm{lbm} / \mathrm{ft}^{3}\left(700 \mathrm{~kg} / \mathrm{m}^{3}\right)$, it was reported to be about $870 \mathrm{lbf} / \mathrm{in}^{2}(6 \mathrm{MPa})$ [1]. Another report showed that for a density range of $31-44 \mathrm{lbm} / \mathrm{ft}^{3}\left(500-700 \mathrm{~kg} / \mathrm{m}^{3}\right)$, the compressive strength was $290-580 \mathrm{lbf} / \mathrm{in}^{2}(2-4 \mathrm{MPa})$ [8]. The relationship between the cube compressive strength and the density of autoclaved aerated concrete is shown in Figure 3 [1].

Examples of values of compressive strength and modulus of elasticity for three densities of dry autoclaved aerated concrete (Table 2) were given by Edlind [28]. He noted that the compressive strength depends on test conditions such as test specimen size, its planeness or type of capping material, and its moisture content. The compressive strength decreases with an increase in moisture content of the material. The relationship between the compressive strength and the moisture content of autoclaved aerated concrete is shown in Figure 4 [1]. With moisture contents of 5 and 10 percent, the compressive strength is reduced about 20 and 25 percent, respectively. In another study by Dworjadkin and Malinowski [65], it was reported that the compressive strength of an autoclaved aerated concrete with maximum water 
saturation ( 40 - 42 percent by volume) was 40 - 50 percent less than that of the air-dried material.

Compressive strength has, in at least one case, been found to decrease with time of exposure. For example, block samples exposed outdoors up to one year were tested by Grimer and Brewer [66] who found changes in strength (as indicated by compressive strength, as well as splitting strength, and modulus of rupture) with time. The decrease ranged from 10 - 15 percent for these properties.

\subsubsection{Tensile Strength}

The tensile strength of autoclaved aerated concrete is normally $1 / 4$ to $1 / 6$ of the compressive strength [1]. Edlind [28] reported the tensile strength to be about 20 percent of the compressive strength. A moisture gradient within the test specimen has a large effect on the tensile strength test result. The measurement of this property is even more sensitive to test conditions than the measurement of the compressive strength.

The tensile strength in bending is normally somewhat higher than when measured in direct tension. A moisture gradient in the specimen also affects this property.

Grimer and Brewer [66] reported that the modulus of rupture of specimens uncovered and stored outdoors changed considerably (up 
to 50 percent decrease) from one month to one year. For specimens covered and also exposed outdoors, no significant change in strength occurred as compared to specimens stored indoors.

The modulus of rupture for a density range of $31-47 \mathrm{lbm} / \mathrm{ft}^{3}$ (500 - $\left.750 \mathrm{~kg} / \mathrm{m}^{3}\right)$ was about $100-190 \mathrm{lbf} / \mathrm{in}^{2}(0.7-1.3 \mathrm{MPa})$ [8]. Cracking in reinforced flexural members was observed to occur between 1.5 and 2.0 times the working load, under which condition the tensile stress can approach 50 percent of the compressive strength of the material.

\subsubsection{Shear and Bond Strength}

The shear rupture strength, based on pure punching shear, can be assumed to be 25 - 30 percent of the compressive strength [1]. The value for pure shear can be taken as that for direct tension, if information about shear strength is not available. The shear strength was also reported to be about $1 / 8$ of the compressive strength and to range from $36-72 \mathrm{lbf} / \mathrm{in}^{2}(0.25-0.5 \mathrm{MPa})$ [8].

In tests reported by Regan [67], the nominal shear stresses in reinforced autoclaved aerated concrete beams at the cracking stage were in the range $51-58 \mathrm{lbf} / \mathrm{in}^{2}(0.35-0.4 \mathrm{MPa})$. This corresponds to the upper limit of values obtained from unreinforced (shear) slabs. The test results suggest that once shear cracking occurs in an autoclaved aerated concrete member, the truss action of the stirrups has to support the full shear with practically no 
separate contribution from the concrete. The increases in strength produced by vertical and transverse stirrups were modest, about 17 percent of the strength of comparable unreinforced beams. However, the use of inclined stirrups was much more effective and increased the ultimate load by almost 50 percent [67].

Based on a statistical evaluation of previously published test results, Briesemann [68] developed semi-empirical methods of calculating the ultimate shearing strength of autoclaved aerated concrete slabs without web reinforcement, as well as the loads resulting in diagonal cracks and shear failure in beams with shear reinforcement. This design method was reported as being useful for components of autoclaved aerated concrete because the test specimens and the components used in practice were identical. The best agreement between the calculated methods and test results was achieved with a linear equation for slabs without shear reinforcement and with a quadratic equation for beams without shear reinforcement.

The bond of reinforcement in autoclaved aerated concrete is normally a fairly plastic phenomenon with the peak stress attained at a slip of about 0.0004 in. $(0.01 \mathrm{~mm})$ and maintained for movements up to about 0.008 in. $(0.2 \mathrm{~mm})$ [67]. Because of the relatively low bond strength, the reinforcement in autoclaved aerated concrete members often relies on welded cross-bars or stirrups which transfer load by bearing $[8,26,43,67]$. 
Regan [67] suggests from pullout tests a limiting value of bond stress for coated plain (smooth round) bars of 180 lbf/in ${ }^{2}(1.25$ MPa) based on the perimeter of the bar not including the coating. The bond strength of plain bars embedded in autoclaved aerated concrete may differ depending on the type of protective coating used. Other pullout tests [26] on small diameter plain bars coated with a cement-latex coating embedded in autoclaved aerated concrete having a compressive strength of $500 \mathrm{lbf} / \mathrm{in}$ ( $3.4 \mathrm{MPa}$ ) yielded bond stresses of $150-200 \mathrm{lbf} / \mathrm{in}^{2}(1.0-1.4 \mathrm{MPa})$ at a slip of 0.001 in. $(0.03 \mathrm{~mm})$ at the free end. Dunn [26] stated that these values are generally greater than those calculated at design load, and actual load tests on precast units confirm that while the bond is adequate for design loads, slip can occur at about 1.25 times design 1oad. Because of this, Dunn [26] further states that welded anchor bars or cross-bars as required in the ACI Guide for Low Density Precast Floor, Roof, and Wall Units [43] are needed to provide an adequate factor of safety.

\subsubsection{Modulus of Elasticity}

The modulus of elasticity is about one tenth that of dense concrete [24]. It has been given as a function of the density and compressive strength of the material. As an example, the modulus of elasticity for autoclaved aerated concrete having a density range of $31-44 \mathrm{lbm} / \mathrm{ft}^{3}\left(500-700 \mathrm{~kg} / \mathrm{m}^{3}\right)$ was reported to be $200-400^{\circ} \times 10^{3} \mathrm{lbf} / \mathrm{in}^{2}\left(1.4-2.8 \times 10^{3} \mathrm{MPa}\right)$ [8]. The moisture content also affects the modulus value. The modulus 
decreases with an increase in moisture content, similar to the way it affects the compressive strength. Moisture effects can be taken into account by using the compressive strength value for the wet material according to the formula below. The formula has been reported to correspond well with test values of some autoclaved aerated concrete produced in sweden having a density range of 25 - $44 \mathrm{lbm} / \mathrm{ft}^{3}\left(400-700 \mathrm{~kg} / \mathrm{m}^{3}\right)$ and a range in moisture contents of 3 - 10 percent by volume [1].

$$
E_{O}=k \gamma_{d r y} \sqrt{f_{C}}
$$

where:

$$
\begin{aligned}
& E_{O} \text { is the tangent modulus, MPa } \\
& Y_{\text {dry }} \text { is the dry density, } \mathrm{kg} / \mathrm{m}^{3} \\
& \mathrm{f}_{\mathrm{C}} \text { is the compressive strength, MPa, for wet material } \\
& \mathrm{k} \text { is an empirical constant, the value reported to vary } \\
& \text { between } 1.5 \text { and } 2.0 \text { [1] }
\end{aligned}
$$

It was noted [1] that this formula can be used by the designer to estimate elastic deformations of unreinforced material even though values obtained from this formula may differ from test results for other autoclaved aerated concrete products.

\subsection{Structure}

The structure of autoclaved aerated concrete is characterized by pores or cells which are formed by the hydrogen gas, air, and water during the molding and expanding phases of production [1]. 
The micro-cellular structure of autoclaved aerated concrete is shown in Figure 5.

Scanning electron microscopy (SEM) micrographs of the cell structure of the hardened material, which is generally considered to be uniform, have been reported $[1,58,59,69,70]$. The pore structure is important with regard to physical properties of the material such as strength, thermal conductivity, capillarity, and frost resistance. Depending on the pore size and their physical characteristics, they can be divided into micropores and macropores. An example of the distribution of pore sizes in autoclaved aerated concrete is given in Figure 6 [1]. Larsson and Purins [60] reported pore size for various kinds of autoclaved aerated concrete investigated in freezing tests. The macropores were determined to have radii of between 64,000 and $550,000 \AA$ and micropores to have radii of between 40 and $64,000 \AA$. They aiso reported that the pore size distribution was different for the various autoclaved aerated concretes investigated. Micropores may be considered to be capillary active, and the distribution of cell sizes within the micropore range is important with regard to properties such as freezing and moisture migration [1]. The macropores are usually almost spherical in shape; however, for cases where they are more oval in shape, it may be assumed that the physical characteristics of the autoclaved aerated concrete may differ somewhat in the directions of the major and minor axes 
[1]. If the cells are irregularly shaped rather than being spherical, excessive reduction in strength occurs [21].

In a study by Schwiete and Ludwig [71], the porosities of some autoclaved aerated concrete specimens were found to be about 70 80 percent. They considered the concept of effective porosity to assess the micropore content of the specimens. They reported that the effective porosities ranged from $4-13$ percent. Moisture contents of the specimens were about 2 percent by volume and the bulk densities were $44 \mathrm{lbm} / \mathrm{in}^{2}\left(700 \mathrm{~kg} / \mathrm{m}^{3}\right)$.

Purins [58] conducted an examination of pore structure and he reported no entirely closed pores in autoclaved aerated concrete. His evidence was electron micrographs of the material with magnifications of up to 26,000 . He observed that the structure was capillary, both at the bottom and in the walls of the pores, and concluded that no closed pores existed in the material.

\subsection{Temperature Resistance}

Shrinkage cracking will result if autoclaved aerated concrete is exposed to dry air at a high temperature for a long time, and excessive drying eventually takes place. For this reason, structural aerated concrete should not be used in constructions that are continuously exposed to dry air at a temperature above 122 $158^{\circ} \mathrm{F}\left(50-70^{\circ} \mathrm{C}\right)$ without protection against excessive drying [1]. For non-structural applications, aerated concrete can be exposed 
to much higher temperatures, up to $1300^{\circ} \mathrm{F}\left(700^{\circ} \mathrm{C}\right)$, if appropriate precautions are taken against excessive drying. The CEB Manual [1] indicates that, for such high temperature use, manufacturers' design considerations must be strictly followed. The melting point of aerated concrete is $1800-2200^{\circ} \mathrm{F}\left(1000-1200^{\circ} \mathrm{C}\right)$, depending on the materials used [1].

\subsection{Thermal Conductivity}

The relatively low thermal conductivity of any cellular concrete is due to air-filled pores [26]. The thermal conductivity, $k$ value, of aerated concrete depends primarily on its density. other factors such as moisture content, temperature level, pore structure, and raw materials also effect the thermal conductivity [1]. The relationship between the thermal conductivity and the density of dry specimens of autoclaved aerated concrete is given in Figure 7 [1]. Based on dry density, the average value of thermal conductivity for a density of $25 \mathrm{lbm} / \mathrm{ft}^{3}\left(400 \mathrm{~kg} / \mathrm{m}^{3}\right)$ was reported to be about $0.55 \mathrm{Btu} \cdot \mathrm{in} . / \mathrm{ft}^{2} \cdot \mathrm{h} \cdot{ }^{\circ} \mathrm{F}(0.08 \mathrm{~W} / \mathrm{mK})$, and for a density of $50 \mathrm{lbm} / \mathrm{ft}^{3}\left(800 \mathrm{~kg} / \mathrm{m}^{3}\right)$, it was reported to be about 1.5 $\mathrm{Btu} \cdot \mathrm{in} \cdot / \mathrm{ft}^{2} \cdot \mathrm{h} \cdot{ }^{\circ} \mathrm{F}(0.21 \mathrm{~W} / \mathrm{mK})[1,10]$. It was reported by Leitch [3] that k-values associated with autoclaved aerated concrete, as with unautoclaved materials, go as low $0.55 \mathrm{Btu} \cdot \mathrm{in} \cdot / \mathrm{ft}^{2} \cdot \mathrm{h} \cdot{ }^{\circ} \mathrm{F}$ $(0.08 \mathrm{~W} / \mathrm{mK})$.

As expected, thermal conductivity increases with an increase in moisture content $[1,10,64,72,73]$. Data in the CEB Manual [1] indicate 
that this relationship is linear for moisture contents up to 20 percent by weight. As an illustration of the relationship, the average value of thermal conductivity for a material with a dry density of $31 \mathrm{lbm} / \mathrm{ft}^{3}\left(500 \mathrm{~kg} / \mathrm{m}^{3}\right)$ was shown to be about $0.76 \mathrm{Btu} \cdot \mathrm{in}$. $/ \mathrm{ft}^{2} \cdot \mathrm{h} \cdot{ }^{\circ} \mathrm{F}(0.11 \mathrm{~W} / \mathrm{mK})$ at zero moisture content, whereas it was shown to be $1.1 \mathrm{Btu} \cdot \mathrm{in} \cdot / \mathrm{ft}^{2} \cdot \mathrm{h} \cdot{ }^{\circ} \mathrm{F}(0.15 \mathrm{~W} / \mathrm{mK})$ at 10 percent moisture content by weight [1]. It was interesting to note, that moisture factors (ratio of thermal conductivity of moist material to that of dry material), determined experimentally by Loudon [72], correlated better with moisture content by weight than moisture content by volume.

For lightweight concretes in general, Valore [74] suggested a single moisture factor that consists of a 6 percent increase in thermal conductivity for each one percent of moisture, by weight, relative to oven dry density. A constant moisture content of 4 percent, by volume, was proposed for lightweight concrete walls having a density of $25 \mathrm{lbm} / \mathrm{ft}^{3}\left(400 \mathrm{~kg} / \mathrm{m}^{3}\right)$, protected from rain penetration. 
5. ENERGY CONSIDERATIONS

As stated in the introduction to this report, a major advantage influencing the use of autoclaved aerated concrete products has been the relatively low thermal conductivity combined with loadcarrying capacity. This factor has been noted by numerous authors who have reported on the properties and performance of autoclaved aerated concretes $[\mathrm{e} . \mathrm{g} ., 1,5-7,10,19,21,24,28,38]$.

Bave $[6,10,38]$ has summarized the development and growth in use of autoclaved aerated concrete, particularly noting the factors affecting energy conservation. The use of this material originated in northern European countries where thermal insulation has been a long time concern due to cold climates and a dependency on imported fuel. Subsequently, its use expanded to warm climates where its low thermal conductivity offered advantages for energy savings in cooling buildings. Bave [6] has indicated that autoclaved aerated concrete, in many geographic locations, satisfies both thermal and loadbearing requirements while offering an overall energy saving. He did not indicate the details of these requirements.

In addition to energy considerations associated with use of a low thermal conductivity material, Bave $[6,10]$ also pointed out qualitatively other factors regarding energy savings in the use of autoclaved aerated concrete. These factors included raw materials, the production process, and transportation and 
erection of the manufactured units. As an example, he stated that the relatively low weight of aerated concrete building units allows cuts in the energy consumption due to handling and erection on site.

Kohler [7] has presented the results of a study on the energy costs for the production and use of autoclaved aerated concrete taking into account direct and indirect energy costs. He compared the energy costs for production of different types of walls having equivalent thermal and loadbearing properties. Among his findings, he reported that the separation of the thermal and loadbearing functions (i.e., composite wall with thermal insulation and structural element) leads generally to lower overall energy costs. For example, he found that the energy costs for a composite autoclaved aerated concrete wall with expanded polystyrene insulation were about 8 percent less than those for the equivalent wall comprised only of autoclaved aerated concrete.

Kohler [7] also modeled the energy performance of complete buildings whereby the use of autoclaved aerated concrete floors, walls, and ceilings was compared to the same elements of conventional materials. A significant finding was that, in the case of energy-efficient houses, "it was not possible to reach the insulation requirements by aerated concrete only even by using very large sections". He indicated that, in these cases, 
autoclaved aerated concrete has to be used together with a material which is specifically a thermal insulation.

In this regard, Kohler's findings may be related to current practice (a.s recommended by ASHRAE) in the U.S. for opaque walls and roofs of new buildings except low-rise residential. For relatively severe climatic locations having 6500 heating degree days or more, the minimum total thermal resistance (R-value) of walls is about 20; whereas for roofs, it is about 30 [75]. An autoclaved aerated concrete wall, 8 in. $(20 \mathrm{~cm})$ thick and having a density of $31 \mathrm{lbm} / \mathrm{ft}^{3}\left(500 \mathrm{~kg} / \mathrm{m}^{3}\right)$ may have an R-value about 11 [28]. A 6 in. $(15 \mathrm{~cm})$ roof slab of similar density material would have an R-value of about 8. Obviously, for both the wall and the roof, additional thermal insulation would be needed to attain an R-value of 20 to 30 . In contrast, in areas of the U.S. having mild climates, autoclaved aerated concrete alone may satisfy insulation needs.

Recently Frey and Briesemann [5] studied the factors affecting the primary energy costs to produce autoclaved aerated concrete. They found that, for the plants studied, raw materials production, raw materials transportation, and actual factory production accounted for 60 percent, 5 percent, and 35 percent of the energy costs, respectively. They indicated that the process is currently very energy efficient, and consequently, substantial energy savings cannot be expected in the future. Where reductions are 
accomplished, they will be associated with improvements in cementitious binder technology. 


\section{STANDARDS AND RELATED DOCUMENTS}

Since autoclaved aerated concrete has been used extensively worldwide, standards and related documents have been developed in many countries. With the exception of the previously mentioned CABO [45] and HUD [46] documents, no standards and codes have been developed in the U.S. Recently, RILEM ${ }^{5}$ Technical Committee 78-MCA on Model Code for Aerated Concrete Based on RILEM Testing Methods [76] has compiled, as a working document, a list of "Standards and Regulations Concerning Building and Buildings Constructed with Autoclaved Aerated Concrete." The titles of these documents, as listed by the RILEM committee, are given in Appendix A. A summary of the contents of these documents is beyond the scope of this review. The contents vary among standards, and some treat a broader range of requirements and use conditions than others. In general, the standards provide: general information on the autoclaved aerated concrete product, minimum requirements for material properties, requirements for the dimensions of specific products (e.g., blocks), test methods, requirements for quality control of the production process, and marking.

$5_{\text {RILEM }}$ is a French acronym for International Union of Testing and Research Laboratories for Materials and Structures. 
7. SUMMARY

This report is a review of the properties and performance of autoclaved aerated concrete. This is a construction material that has gained widespread use in many areas of the world. Iittle use has occurred in Canada and the United States. It is a lightweight porous concrete whose cellular structure is generally obtained through an in situ gas-producing reaction. Subsequent autoclaving in the factory provides strength, dimensional stability, and other properties of the finished product. These materials combine a relatively low thermal conductivity with a bearing capacity suitable for use in structural applications. This combination of properties might make them attractive for energy-conserving applications. For this reason, the review was conducted at the request of the U.S. Department of Energy.

The review addressed an overview of the manufacturing process, uses of autoclaved aerated concrete in building constructions, properties, energy considerations, the availability of code-related documents, and standards. The literature on these materials is extensive. Uses include block and panel construction in both loadbearing and non-loadbearing applications for walls, floors, and roofs. With regard to energy considerations, the review pointed out that, for energy efficient applications under severe climate conditions, the autoclaved aerated concrete unit alone may be insufficient to provide the targeted minimum value of thermal resistance. In these cases, autoclaved aerated concrete 
has to be used together with additional thermal insulation. In contrast, in areas of the U.S. having mild climates, autoclaved aerated concrete alone may satisfy insulation needs. 


\section{ACKNOWLEDGMENTS}

This study was sponsored by the U.S. Department of Energy, Office of Conservation and Renewable Energy. The authors appreciate the support and assistance of William Gerken (DOE) and David McElroy (ORNL) who both provided liaison between DOE and NBS. The authors also thank their NBS colleagues, James Pielert, James Clifton, Geoffrey Erohnsdorff, and Daniel Gross who gave important review comments on this report. The authors acknowledge the excellent support of Denise Herbert for typing the manuscript. Finally, special thanks are expressed to Samuel Aroni, University of California at Los Angeles, Poul Nerenst, $H+H$ Industri, Denmark, and Gunnar Bave, Siporex, Sweden, who visited NBS to discuss their experiences regarding the properties and performance of autoclaved aerated concretes. Their valuable review comments on this report are appreciated. 
9. REFERENCES

1. "Autoclaved Aerated Concrete -- CEB Manual of Design and Technology," Comité Euro-International du Beton (CEB), The Construction Press, New York (1978), 90 pages.

2. Tabak, R., "Differential Thermogravimetric Analysis in Autoclaved Cellular Concrete Research, Thermal Analysis, Vol.3, Proceedings 4th ICTA, Budapest (1974) pp. 525-532.

3. Leitch, F.N., "The Properties of Aerated Concrete in Service" Proceedings of the Second International Congress on Lightweight Concrete, the Concrete Society, London (14-15 April 1980) pp. 97-113.

4. Bessey, G.E., "The History and Present Day Development of the Autoclaved Calcium Silicate Building Products Industries," Proceedings of the Symposium, Autoclaved Calcium Silicate Building Products, University of London, Society of the Chemical Industry (18-21 May 1965), pp. 3-6.

5. Erey, E. and Briesemann, D., "More Recent Calculations of the Primary Energy Costs of Autoclaved Aerated Concrete," Betonwerk and Fertigteil-Technik, No. 7 91985), pp. 468-472.

6. Bave, G., "Climatic Conditions and Energy," in "Autoclaved Aerated Concrete, Moisture and Properties," F.H. Wittmann, Ed., Elsevier, Amsterdam (1983), pp. 1-12.

7. Kohler, N., "Global Energetic Budget of Aerated Concrete," in "Autoclaved Aerated Concrete, Moisture and Properties," F.H. Wittmann, Ed., Elsevier, Amsterdam (1983), pp. 13-26.

8. "Autoclaved Aerated Concrete," Building Digest 86, Central Building Research Institute, India (December 1970), 3 pages.

9. Korovkevich, V.V., "The Use of Low-Density Aerated Concrete in Load-Bearing structures for Residential and Public Buildings in the U.S.S.R.," Proceedings, 1st International Congress on Lightweight Concrete, Vol. 2, Cement and Concrete Association, London (May 1968), p. 179.

10. Bave, G., "Aerated Concrete - How it Conserves Energy," Housing Science, Vol. 5, No. 1 (1981), pp. 73-81.

11. Bessey, G.E., "Author's Introduction," Proceedings, 1st International Congress on Lightweight Concrete, Vol. 2, Cement and Concrete Association, London (May 1968), p. 161.

12. Bessey, G.E., "The World Development and Economic Significance of the Aerated Concrete Industry," Proceedings, 1st International Congress on Lightweight Concrete, Vol. 1 , 
Cement and Concrete Association, London (May 1968), pp. 203-212.

13. Valore, Rudolph C., Jr., "Cellular Concretes, Part 1, Composition and Methods of Preparation," ACI Journal Vol. 25 (May 1954), pp. 773-796.

14. "Concrete Product Gets First U.S. Use," Building Design and Construction, Vol. 27, No. 6, June 1986, p. 26.

15. Houst, Y. and Wittmann, F.H., "Bibliography on Autoclaved Aerated Concrete," in "Autoclaved Aerated Concrete, Moisture and Properties," F.H. Wittmann, Ed., Elsevier, Amsterdam (1983), pp. 325-369.

16. "Autoclaved Aerated Concrete, Moisture and Properties," Wittmann, F.H., Developments in Civil Engineering, 6, Elsevier, Amsterdam (1983), 380 pages.

17. Valore, Rudolph C., Jr., "Cellular Concretes, Part 2, Physical Properties," ACI Journal, Vol. 25 (June 1954), pp. $817-836$.

18. Urmston, W.B. and Bessey, G.E., "Structural Lightweight Concrete Using Lightweight Aggregates with Aeration," Chemistry and Industry (7 April 1973), pp. 300-307.

19. Merlet, Jean-Daniel, "Cellular Autoclaved Concrete," CSTB Magazine, No. 23 (January-February 1984), p. 2.

20. Ironman, Ralph, "Cellular Concrete Gains Worldwide Strength," Concrete Products (July 1977).

21. Shrivastava, O.P., "Lightweight Aerated or Cellular Concrete - A Review," Indian Concrete Journal (January 1977), pp. 1823 .

22. Kritov, V.A., Skatynsky, V.I., Chikota, E.I., and Udachkin, I.B., "Building Enclosing Structures Made of Energy Saving Autoclave Concrete," Proceedings, CIB 83 (1983), pp. 145152 .

23. Bennett, R.P., Furgeaud, R. and Paljak, I., "Le Beton Cellulaire Autoclavé: Proprietes et Utilisations," Annales de L'Institute Technique du Batiment et des Travaux Public, No. 376 (October 1979), pp. 74-102.

24. "Autoclaved Aerated Concrete," Building Research Establishment Digest, Digest 178, Building Research Station, Garston, Watford (June 1975), 4 pages. 
25. Schulze, W. and Gunzler, J., "Corrosion Protection of the Reinforcement in Lightweight Concrete," Proceedings, 1st International Congress on Lightweight Concrete, Vol. 1, Cement and Concrete Association, London (May 1968), pp. 111122 .

26. Dunn, R. Hunter, "Precast Low Density Concrete Units," Paper SP 29.9, Lightweight Concrete, Publication SP 29, American Concrete Institute, Detroit, MI (1971), pp. 147-159.

27. Crosier, C.M., "Effects of Variations in Curing Factors on the Strength of Autoclaved Aerated Concrete," Paper SP 3210, in "Menzel Symposium on High Pressure Steam Curing," Publication SP-32, American Concrete Institute, Detroit, MI (1972), pp. 193-219.

28. Edlind, O., "Some Properties and Practical Aspects of Hardened Aerated Concrete: Swedish Experience," Proceedings, 1st International Congress on Lightweight Concrete, Vol. 1, Cement and Concrete Association, London (May 1968), pp. 77-87.

29. Svanholm, G., "The Use of Storey High Units of Aerated Concrete for External Walls and for Cellars," Proceedings, 1st International Congress on Lightweight Concrete, Vol. 2, Cement and Concrete Association, London (May 1968), pp. 7682 .

30. Wennstrom, I., "The Use of Aerated Concrete Units for LowRise Housing: Planning and Design, Architectural Properties and Some Experience with Completed Houses," Proceedings, 1st International Congress on Lightweight Concrete, Vol. 1, Cement and Concrete Association, London (May 1968), pp. 6575 .

31. Nettleton, C.N., "Advantages and Limitations of Large Aerated Concrete Units," Proceedings, 1st International Congress on Lightweight Concrete, Vol. 2, Cement and Concrete Association, London (May 1968), pp. 164-165.

32. Makarichev, A.A., "Author's Introduction," Proceedings, 1st International Congress on Lightweight Concrete, Vol. 2, Cement and Concrete Association, London (May 1968), pp. 161-163.

33. Gemmel, C., "Developments in the Use of Aerated Concrete in Sweden," Proceedings, 1st International Congress on Lightweight Concrete, Vol. 2, Cement and Concrete Association, London (May 1968), pp. 90-91.

34. Purvis, J.F., "Finishes on Aerated Concrete," Proceedings of the Symposium, Autoclaved Calcium Silicate Building Products, University of London, Society of the Chemical Industry (1821 May 1965), pp. 252-258. 
35. Stromberg, J., "Some Technical Data Concerning a New Type of Tongue-and-Groove Joints for Roof Slabs of Cellular concrete," Proceedings of the Symposium, Autoclaved Calcium Silicate Building Products, University of London, Society of the Chemical Industry (18-21 May 1965), pp. 234-238.

36. Bave, G., "New Applications of Siporex Large Size Aerated Concrete Units," Proceedings of the Symposium, Autoclaved Calcium Silicate Building Products, University of London, Society of the Chemical Industry (18-21 May 1965), pp. 230233 .

37. Ulanichev, P.V., "The Various Products of an Aerated Concrete Factory in the U.S.S.R," Proceedings, 1st International Congress on Lightweight Concrete, Vol. 2, Cement and Concrete Association, London (May 1968), pp. $165-166$.

38. Bave, G., "Aerated Lightweight Concrete - Current Technology,," Proceedings of the Second International Congress on Lighweight Concrete, The Concrete Society, London (14-15, April 1980), pp. 28-35.

39. Tietz, S.B., "Some Problems with Aerated Concrete, "Proceedings, 1st International Congress on Lightweight Concrete, Vol. 2, Cement and Concrete Association, London (May 1968), pp. 188189 .

40. Eden, N.B., Manthrope, A.R., Miell, S.A., Szymanek, P.H., and Watson, K.I., "Autoclaved Aerated Concrete From Slate Waste - Part 1: Some Property/Density Relationships," International Journal of Lightweight Concrete, Vol.2, No. 2 (June 1980), pp. 95-100.

41. Polyakov, S.V. and Y.I. Kotov, "The Strength and Deformation of Aerated and Lightweight-aggregate Concrete Under Repeated Dynamic Loads," Proceedings, 1st International Congress on Lightweight Concrete, Vol. 2, Cement and Concrete Association, London (May 1968), pp. 113-118.

42. Briesemann, Dietmar, "Structural Elements and Masonry of Autoclaved Aerated Concrete," in "Autoclaved Aerated Concrete, Moisture and Properties," F.H. Wittmann, Ed., Elsevier, Amsterdam (1983), pp. 257-266.

43. "Guide for Low Density Precast Concrete Floor, Roof, and Wall Units," ACI 523.2R68, Report by ACI Committee 523, American Concrete Institute, Detroit, MI (Revised 1982), 6 pages. 
44. "Building Code Requirements for Reinforced Concrete (ACI 318-83)," ACI 318-83, American Concrete Institute, Detroit, MI (September 1984), 111 pages.

45. Council of American Building Officials, Report No. NRB-192, (April 1984), 4 pages.

46. U.S. Department of Housing and Urban Development, Materials Release No. 1062a (March 19, 1984), 5 pages.

47. Kinniburgh, W., "Moisture Content and Moisture Migration in Aerated Concrete," Proceedings of the Symposium, Autoclaved Calcium Silicate Building Products, University of London, Society of the Chemical Industry (18-21 May 1965), pp. 174181 .

48. "A Guide to the Use of Waterproofing, Dampproofing, Protective and Decorative Barrier systems for Concrete," ACI 515.1R-79, Report by ACI Committee 515, American Concrete Institute, Detroit, MI (September 1984), 41 pages.

49. Ahlstedt, E.T., "The Quality of Aerated Concrete Products in Sweden," Proceedings, 1st International Congress on Lightweight Concrete, Vol. 2, Cement and Concrete Association, London (May 1968), pp. 103-104.

50. Aldrin, L. "Dimensional Accuracy of Aerated Concrete Wall Units," Proceedings, 1st International Congress on Lightweight Concrete, Vol. 2, Cement and Concrete Association, London (May 1968), pp. 82-84.

51. Nakano, S. and Tada, S., "Optimum Performance Design for Cellular Concrete Outer Wall," Proceedings of the 3rd ASTM/CIB/RILEM Symposium, Performance Concept in Building (March 29,30,31 - April 1,2, 1982) pp. 373-385.

52. Cividini, B., "Investigation of Long Time Deflection on Reinforced Aerated Concrete Slabs," in "Autoclaved Aerated Concrete, Moisture and Properties," F.H. Wittmann, Ed., Elsevier, Amsterdam (1983), pp. 267-282.

53. Kruml, R., "Influence of Saturation Degree on Autoclaved Aerated Concretes on their Creep," in "Autoclaved Aerated Concrete, Moisture and Properties," F.H. Wittmann, Ed., Elsevier, Amsterdam (1983), pp. 249-256.

54. Nielsen, A., "Some Experiments on the Creep of Aerated Concrete," Proceedings, 1st International Congress on Lightweight Concrete, Vol. 2, Cement and Concrete Association, London (May 1968), pp. 105-106. 
55. Houst, Y., Alou, F., and Wittmann, F.H., "Influence of Moisture Content on Mechanical Properties of Autoclaved Aerated Concrete," in "Autoclaved Aerated Concrete, Moisture and Properties," F.H. Wittmann, Ed., Elsevier, Amsterdam $(1983)$, pp. 219-234.

56. Nakano,S. and Tada, S., "Durability Criteria for Cellular Concrete Outer Wall," Proceedings, 2nd International Conference on the Durability of Building Materials and Components, National Bureau of Standards (U.S.) (14-16 September 1981), pp. 232-241.

57. Ryan, J.V. and Bender, E.W., "Fire Tests of Precast Cellular Concrete Floors and Roofs," NBS Monograph 45 (April 12, $1962), 12$ pages.

58. Purins, E., "The Frost Resistance of Aerated Concrete," Proceedings, 1st International Congress on Lightweight Concrete, Vol. 2, Cement and Concrete Association, London (May 1968), pp. 94-100.

59. Roulet, C.A., "Expansion of Aerated Concrete Due to FrostDetermination of Critical Saturation," in "Autoclaved

Aerated Concrete, Moisture and Properties," F.H. Wittmann, Ed., Elsevier, Amsterdam (1983), pp. 157-170.

60. Larsson, L. and Purins, E., "Determination of the Critical Degree of Saturation for Autoclaved Lightweight Aerated Concrete by Studying Deformations in Single-Cycle Freezing Tests," International Journal of Lightweight Concrete, Vol. 2, No. $1(1980)$, pp. 33-41.

61. Jennings, B.M., "Versatility and Serviceabilty of Aerated Concrete Units," Proceedings, 1st International Congress on Lightweight Concrete, Vol. 2, Cement and Concrete Association, London (May 1968), pp. 82-86.

62. Custance, R.M., "Fixings to Autoclaved Aerated Concrete Building Elements," Proceedings of the Symposium, Autoclaved Calcium Silicate Building Products, University of London, Society of the Chemical Industry (18-21 May 1965), pp. 216219).

63. Grimer, F.J. and Brewer, R.S., "The within Cake Variation of Autoclaved Aerated Concrete," Proceedings of the Symposium, Autoclaved Calcium Silicate Building Products, University of London, Society of the Chemical Industry (18-21 May 1965), pp. $163-170$.

64. Svanholm, G., "Influence of Water Content on Properties," in "Autoclaved Aerated Concrete, Moisture and Properties," F.H. Wittmann, Ed., Elsevier, Amsterdam (1983), pp. 119-130. 
65. Dworjadkin, A. and Maalinowski, R., "Porosity, Compressive Strength and Volume Changes of Autoclaved Aerated Concrete," Proceedings of the Symposium, Autoclaved Calcium Silicate Building Products, University of London, Society of the Chemical Industry (18-21 May 1965), pp. 174-181.

66. Grimer, F.J. and Brewer, R.S., "The Effect of the Environment on the Strength of Autoclaved Aerated Concrete," Proceedings of the Symposium, Autoclaved Calcium Silicate Building Products, University of London, Society of the Chemical Industry (18-21 May 1965), pp. 182-187.

67. Regan, P.E., "Shear in Reinforced Aerated Concrete," International Journal of Lightweight Concrete, Vol. 1, No. 2 (1979), pp. 47-61.

68. Briesemann, D., "A Method of Calculating the Shear Resistance of Reinforced Slabs and Beams of Autoclaved Aerated Concrete," International Journal of Lightweight Concrete, Vol. 2, No. 1 , (1980), pp. 21-31.

69. Tada, S. and Nakano, S. "Microstructural Approach to Properties of Moist Cellular Concrete," in "Autoclaved Aerated Concrete, Moisture and Properties," F.H. Wittmann, Ed., Elsevier, Amsterdam (1983), pp. 71-90.

70. Prim, P. and Wittmann, F.H., "Structure and Water Absorption of Aerated Concrete," in "Autoclaved Aerated Concrete, Moisture and Properties," F.H. Wittmann, Ed., Elsevier, Amsterdam (1983), pp. 55-69.

71. Schwiete, H.E. and Ludwig, U., "The Porosity and Gas Permeability of Aerated Concrete," Proceedings of the Symposium, Autoclaved Calcium Silicate Building Products, University of London, Society of the Chemical Industry (1821 May 1965), pp. 188-194.

72. Loudon, A.G., "The Effect of Moisture Content on Thermal Conductivity," in "Autoclaved Aerated Concrete, Moisture and Properties," F.H. Wittmann, Ed., Elsevier, Amsterdam (1983), pp. 131-142.

73. Hums, Dieter, "Relation Between Humidity and Heat Conductivity in Aerated Concrete," in "Autoclaved Aerated Concrete, Moisture and Properties," F.H. Wittmann, Ed., Elsevier, Amsterdam (1983), pp. 143-152.

74. Valore, R.C., Jr., "Calculation of U-Values of Hollow Concrete Masonry," Concrete International - Design \& Construction, Vol. 2, No. 2 (February 1980), pp. 40-63. 
75. ASHRAE Standard ANSI/ASHRAE/IES 90.1 P, "Proposed American National Standard for Energy Efficient Design of New Buildings Except Low-Rise Residential Buildings," Chapter 8 (August 22, 1986), p. 8-58.

76. Wittmann, F.H. and Houst, Y., "Standards and Regulations Concerning Building and Buildings Constructed with Autoclaved Aerated Concrete," 2nd Revised Version, Working Document, RILEM Technical Committee 78-MCA. 


\section{COUNTRIES USING AUTOCLAVED AERATED CONCRETE}

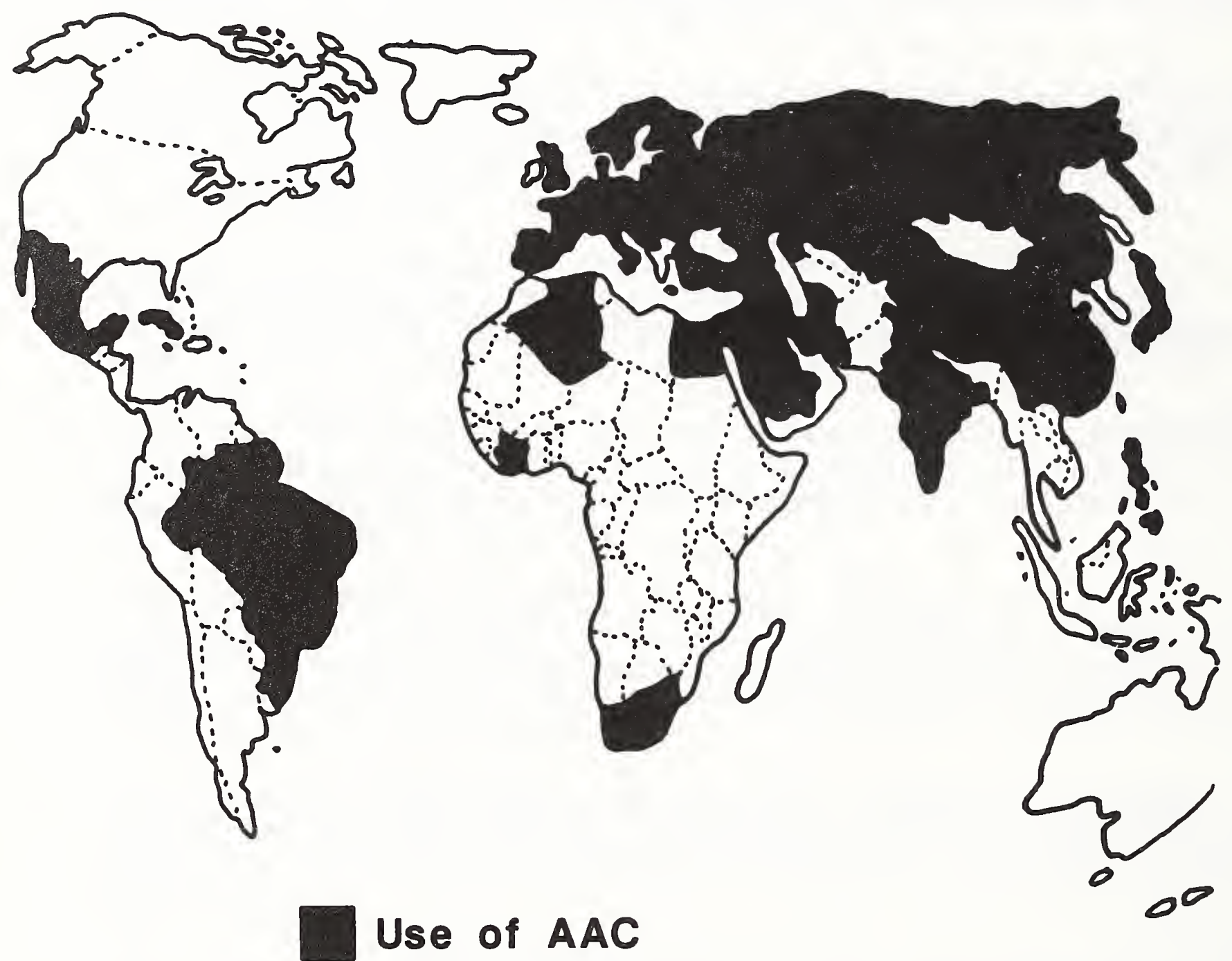

Figure 1. Countries where Autoclaved Aerated Concrete (AAC) is Used, As Described by Bave in 1983 [6]. 


\section{STEPS IN MANUFACTURING PROCESS}

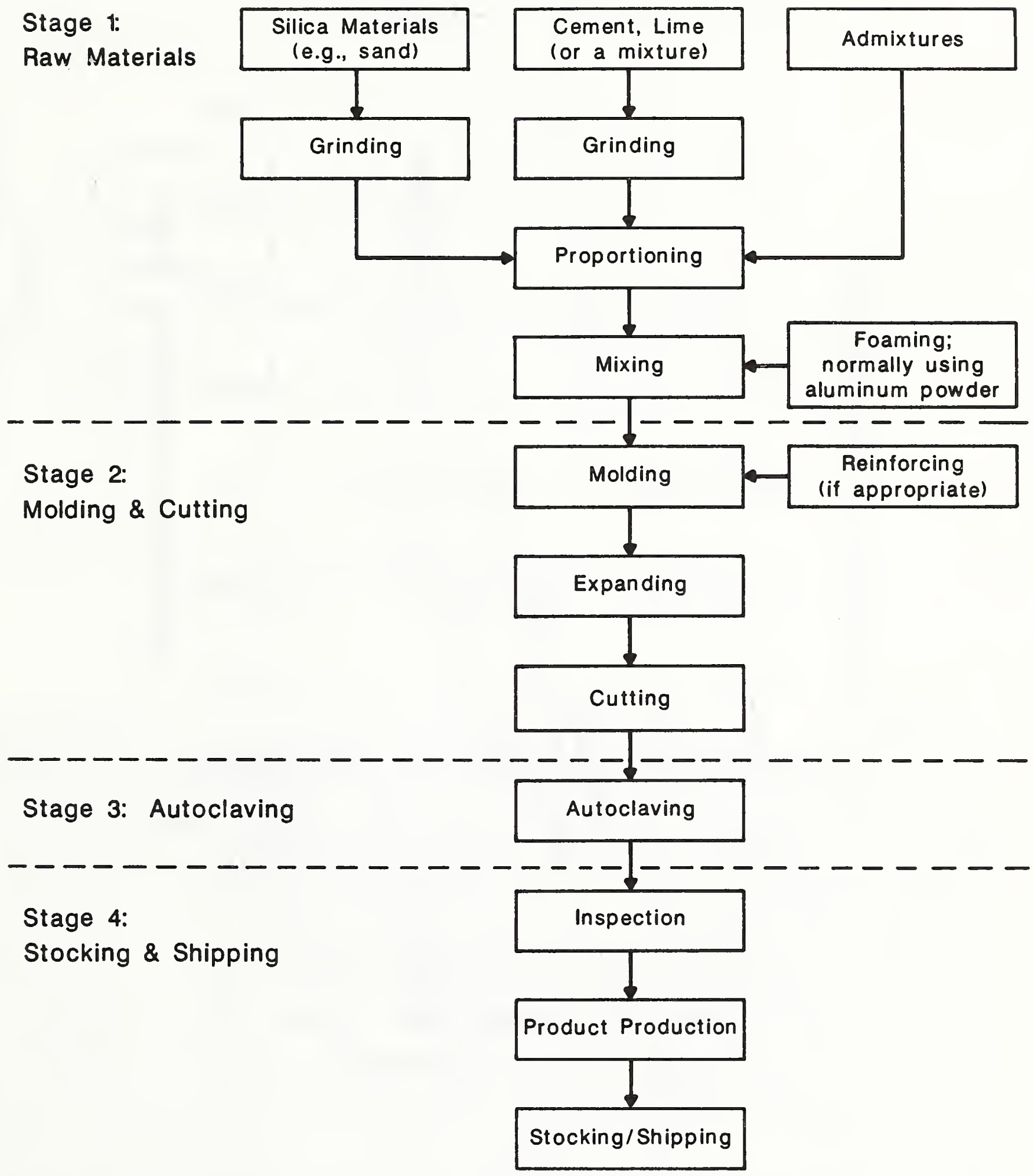

Figure 2. Production of Autoclaved Aerated Concrete Products. 


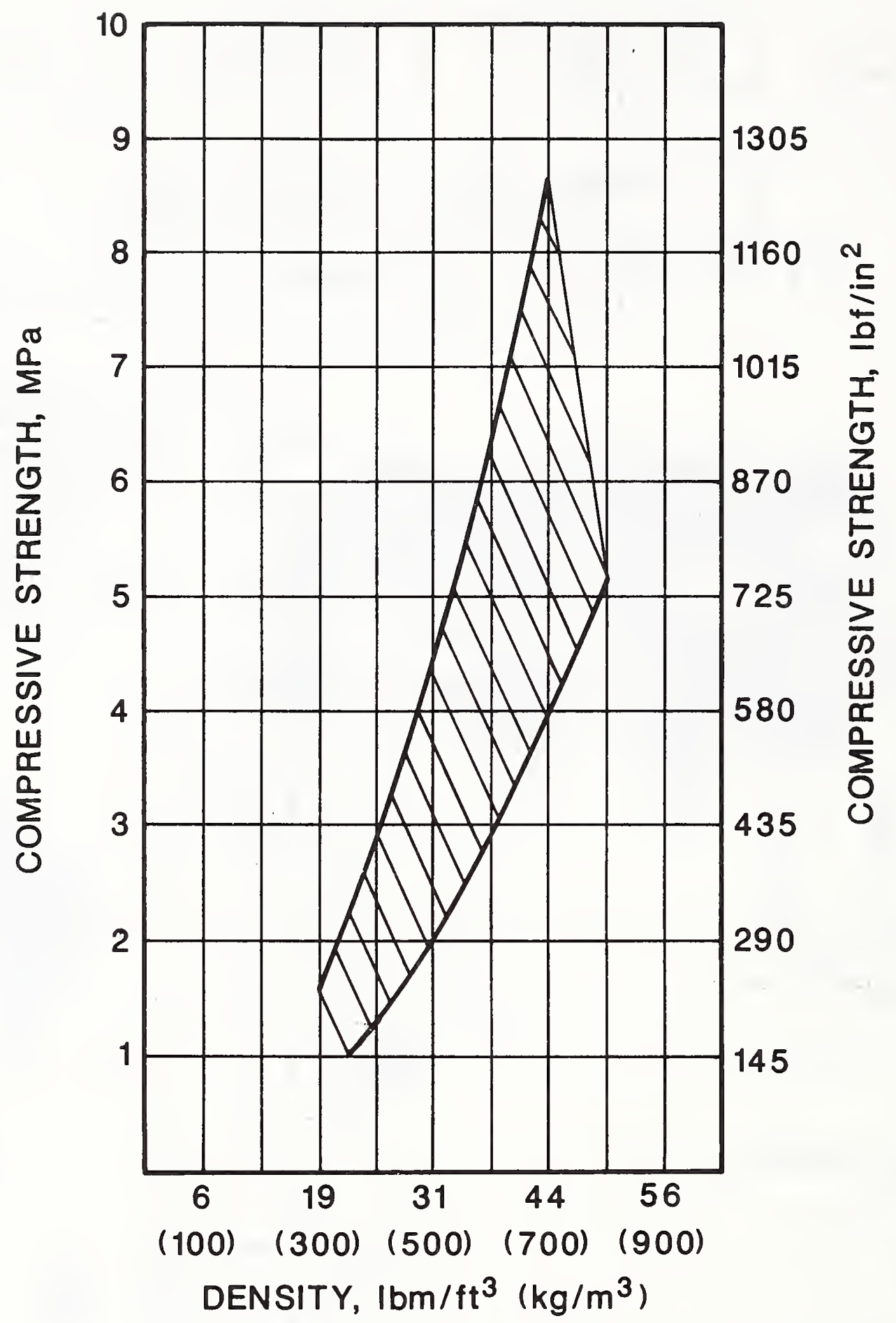

Figure 3. Relationship Between the Cube Compressive Strength and the Density of Autoclaved Aerated Concrete (From CEB Manual [1], Courtesy of CEB and the Construction Press). 


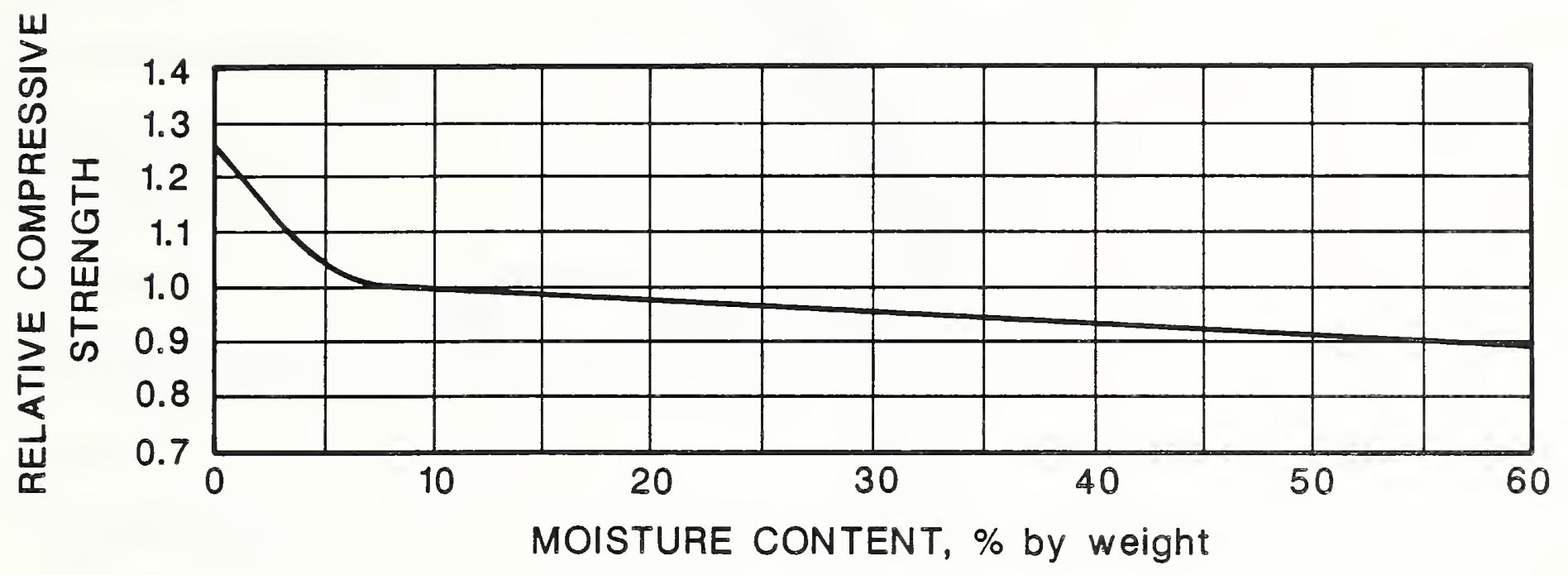

Figure 4. Relationship Between the Compressive Strength and the Moisture Content of Autoclaved Aerated Concrete (From CEB Manual [1], Courtesy of CEB and the construction Press).

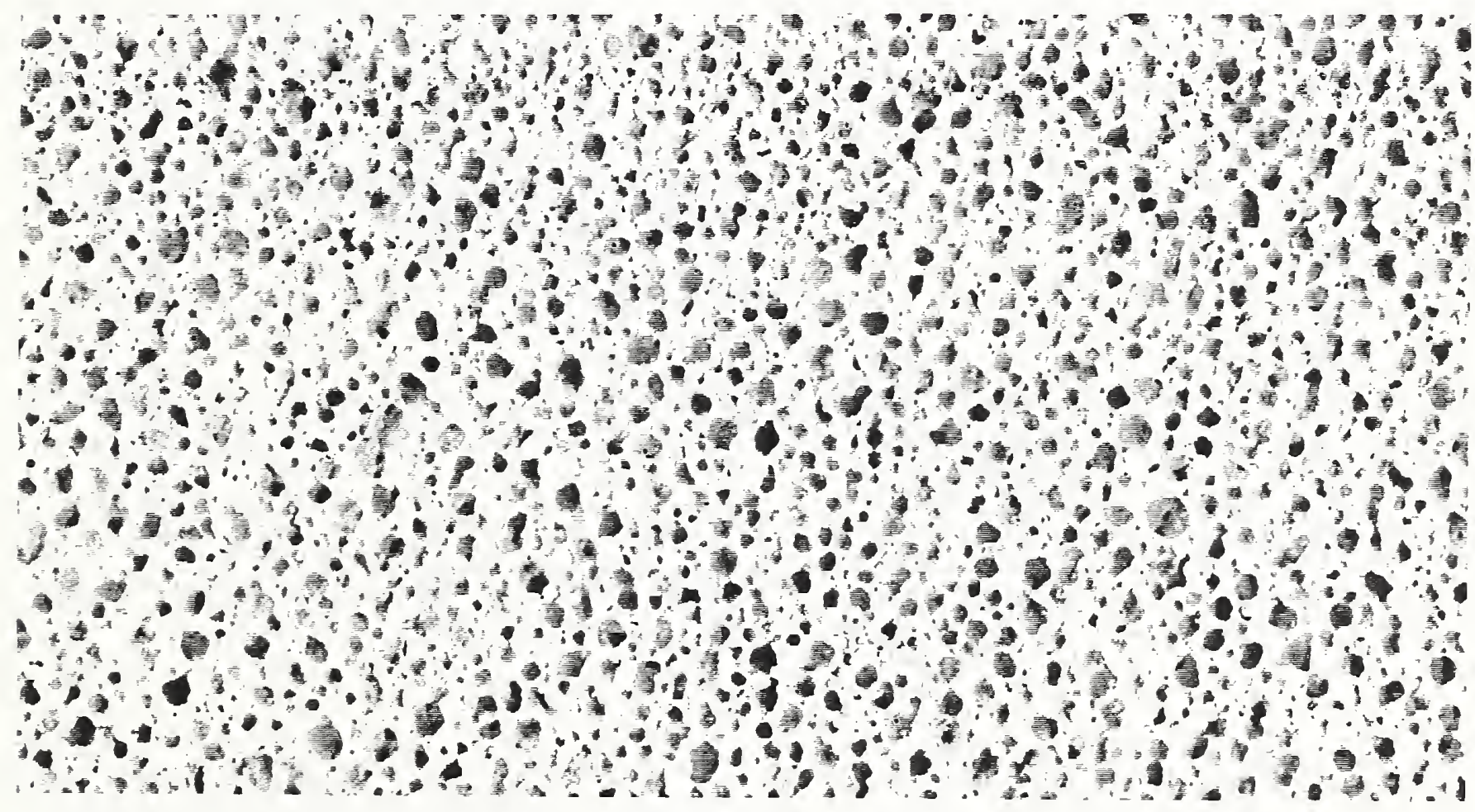

Figure 5. The Micro-Cellular Structure of Autoclaved Aerated Concrete (Magnified to About $3 \times$ Acutal Size). 


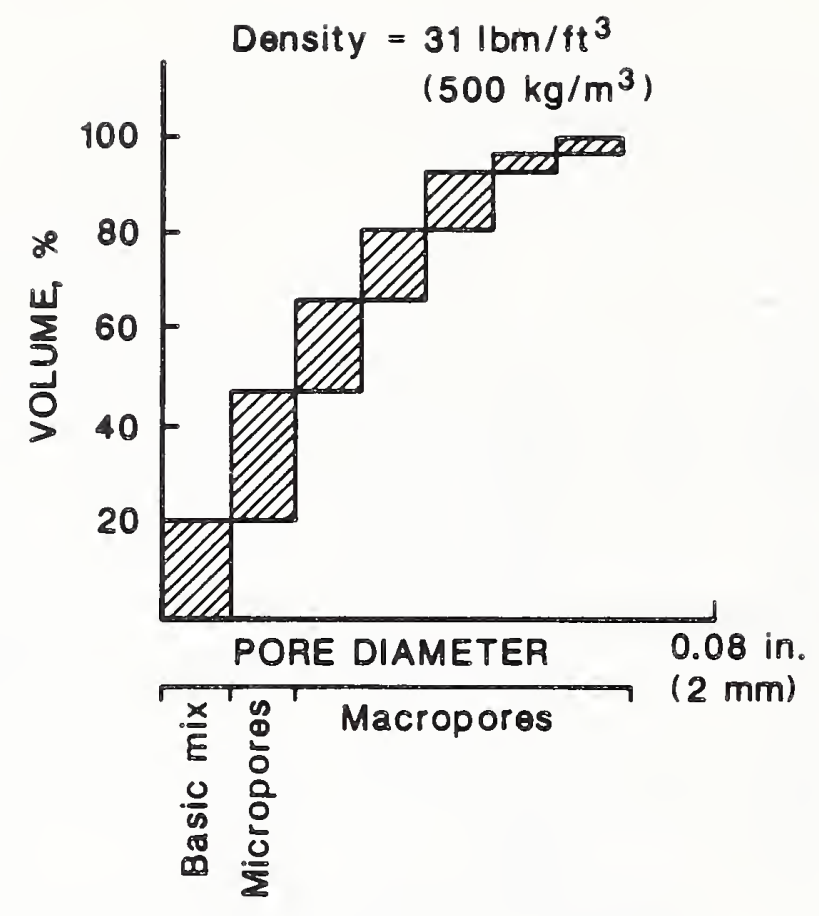

Figure 6. Example of Distribution of Pore Sizes in Autoclaved Aerated Concrete (from CEB Manual [1], Courtesy of CEB and the Construction Press).

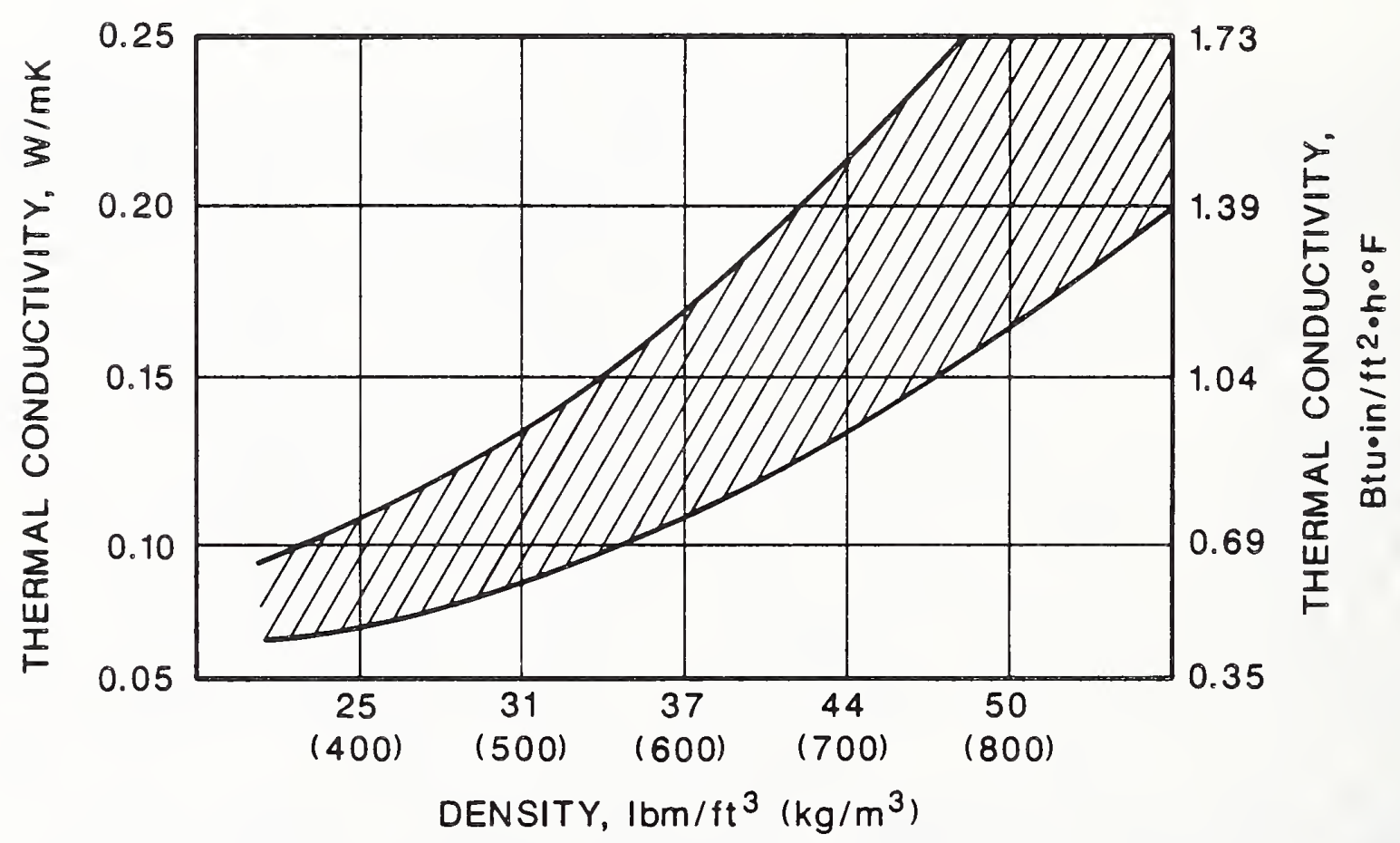

Figure 7. The Relationship Between the Thermal Conductivity and the Density of Dry specimens of Autoclaved Aerated Concrete (from CEB Manual [1], Courtesy of CEB and the Construction Press). 
Table 1. Estimated 1987 Production of Autoclaved Aerated Concrete in some Countries ${ }^{1}$

country

\begin{tabular}{lrr} 
& \multicolumn{1}{c}{$\mathrm{ft}^{3}$} & $\mathrm{~m}^{3}$ \\
\hline Belgium & $8.8 \times 10^{6}$ & $250 \times 10^{6}$ \\
Czechoslovakia & $105.9 \times 10^{6}$ & $3000 \times 10^{3}$ \\
Denmark & $10.6 \times 10^{6}$ & $300 \times 10^{3}$ \\
Finland & $7.1 \times 10^{6}$ & $200 \times 10^{3}$ \\
France & $17.6 \times 10^{6}$ & $500 \times 10^{3}$ \\
Federal Republic of Germany & $97.1 \times 10^{6}$ & $2750 \times 10^{3}$ \\
Japan & $105.9 \times 10^{6}$ & $3000 \times 10^{3}$ \\
Netherlands & $10.6 \times 10^{6}$ & $300 \times 10^{3}$ \\
Poland & $141.3 \times 10^{6}$ & $4000 \times 10^{3}$ \\
Sweden & $8.8 \times 10^{6}$ & $250 \times 10^{3}$ \\
Soviet Union & $187.2 \times 10^{6}$ & $5300 \times 10^{3}$ \\
United Kingdom & $100.6 \times 10^{6}$ & $2850 \times 10^{3}$ \\
Yugoslavia & $35.3 \times 10^{6}$ & $1000 \times 10^{3}$
\end{tabular}

1 Gunnar Bave, Siporex, personal communication

Table 2. Examples of Values of Compressive Strength and Modulus of Elasticity [28]

\section{Density}

$\mathrm{kg} / \mathrm{m}^{3} \quad \mathrm{lbm} / \mathrm{ft}^{3}$

$400 \quad 25$

$500 \quad 31$

650
Compressive Strength

MPa

1.5

3.0

6.5
$1 \mathrm{bf} / \mathrm{in}^{2}$

215

430

924
Modulus of Elasticity

MPa $\quad 1 b f /$ in $^{2}$

1000

142,230

1400

199,130

2600

369,810 

APPENDIX A. LISTING OF STANDARDS AND RELATED DOCUMENTS

This appendix lists standards and related documents for autoclaved aerated concrete products (Table A1). The listing was assembled from the working document prepared by RILEM Technical Committee 78-MCA on Model Code for Aerated Concrete Based on RILEM Testing Methods [76] as part of its activities to recommend an application practice for autoclaved aerated concrete. As is evident from the listing, some of the titles of the documents are given in their language of origin. In these cases, only the original language was given in the RILEM working document. The ASTM documents included in the listing are not specific for autoclaved aerated concrete. 
Table A1. Standards and Related Documents Associated With Autoclaved Aerated Concrete

NBN 538 (1962)
Blocs en beton pour maconnerie ordinaire
DS 420.1 (1967)
Vandrette baerende elementer af armeret autoklaveret
letbeton
Ds 420.1 (1967) (Supplement)
Vandrette baerende elementer af armeret autoklaveret
letbeton
DS 420.2 (1977)
Vertical load bearing elements of lightweight concrete
DS 420.3 (1980)
Letbeton vandretbaerende elementer
DS 438 (1981)
Blokmurvaerk

Federal

Republic of Germany
DIN 4223 (1958)

Bewehrte Dach- und Deckenplatten aus dampfgehartetem Gas - und Schaumbeton

Entfurf DIN 4223 (1978)

Bewehrte Bauteile

DIN 4164 (1951)

Gas- und Schaumbeton - Herstullung, Verwendung und Prufung

DIN 4165 (1982)

Gasbeton-Blocksteine

DIN 4166 (1973)

Gasbeton-Bauplatten

Zulassungsbescheid Nr. Z 17.1-1387 (1981)

Mauerwerk aus Hebel-Plansteinen

Zulassungsbescheid Nr. Z 17.1-43 (1975)

Geschosshohe tragende Hebel-Wandtafeln aus dampfgehartetem Gasbeton der Festigkeitsklassen G 35 und G 50

Zulassungsbescheid Nr. Z 2.1-5.1 (1982)

Bewehrte Hebel-Deckenplatten aus dampfgehartetem Gasbeton der Festigkeitsklassen GB 3.3 (GSB 35) und GB 4.4 (GSB 50)

$$
\text { A }-2
$$


Table Al. Standards and Related Documents Asociated With Autoclaved Aerated Concrete (continued)

Finland

France

German

Democratic

Republic

Standard

Zulassungsbescheid $\mathrm{Nr}, \mathrm{Z} 2.1-5.2$ (1982)

Bewehrte Hebel-Dachplatten aus dampfgehartetem Gasbeton

der Festigkeitsklassen GB 3.3 (GSB 35 ) und GB 4.4 (GSB 50)-

Zulassungsbescheid $\mathrm{Nr}$. Z 2.1-23 (1982)

Bewehrte Hebel-Sturze aus dampfgehartetem Gasbeton

GB 4.4 (GSB 50) ohne schragbewehrung

RIL 69 (1969)

Karkaistun kevytbetonin normit 1969

NF P 14-306 (1978)

Blocs en beton cellulaire autoclavé pour murs

Avis no $16 / 75-20$ (1976)

Avis sur le mur en blocs de beton cellulaire Ytong (Burcht)

Avis no 3/77-58 (1978)

Avis sur le plancher Siporex (Bernon)

Avis no $16 / 77-29$ (1978)

Avis sur le procede de maconnerie sipobloc (Bernon)Durobloc (Bernon)

TGL 21098 (1972)

Gasbeton - Technische Forderungen

TGL 21098 (1972)

Gasbeton - Prufung

TGL 23374 (1971)

Wandplatten fur den Skelettbau - Fensterplatten aus Stahibeton

TGL 23374 (1974)

Wandplatten fur den Skelettbau - Aussenwandvollplatten aus Gasbeton

TGL 23374/02 (1975)

Wandplatten fur den Skelettbau - Einschichtige

Aussenwandelemente aus Leicht- und Schwerbeton

TGL 25553 (1972)

Wandbausteine aus Gasbeton

$$
\text { A }-3
$$


Table A1. Standards and Related Documents Associated With Autoclaved Aerated Concrete (continued)

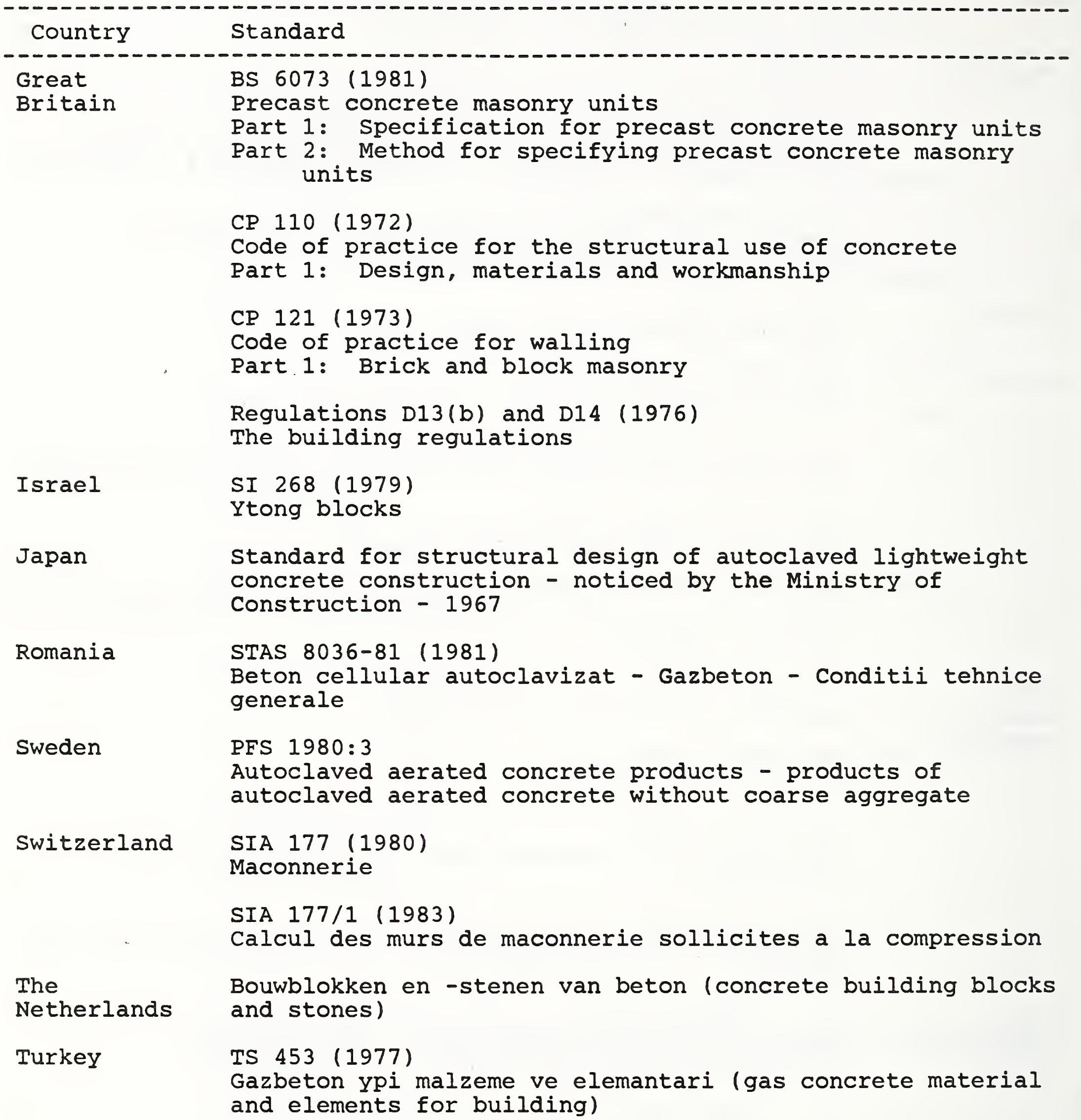

$$
A-4
$$


Table A1. Standards and Related Documents Associated With Autoclaved Aerated Concrete (continued)

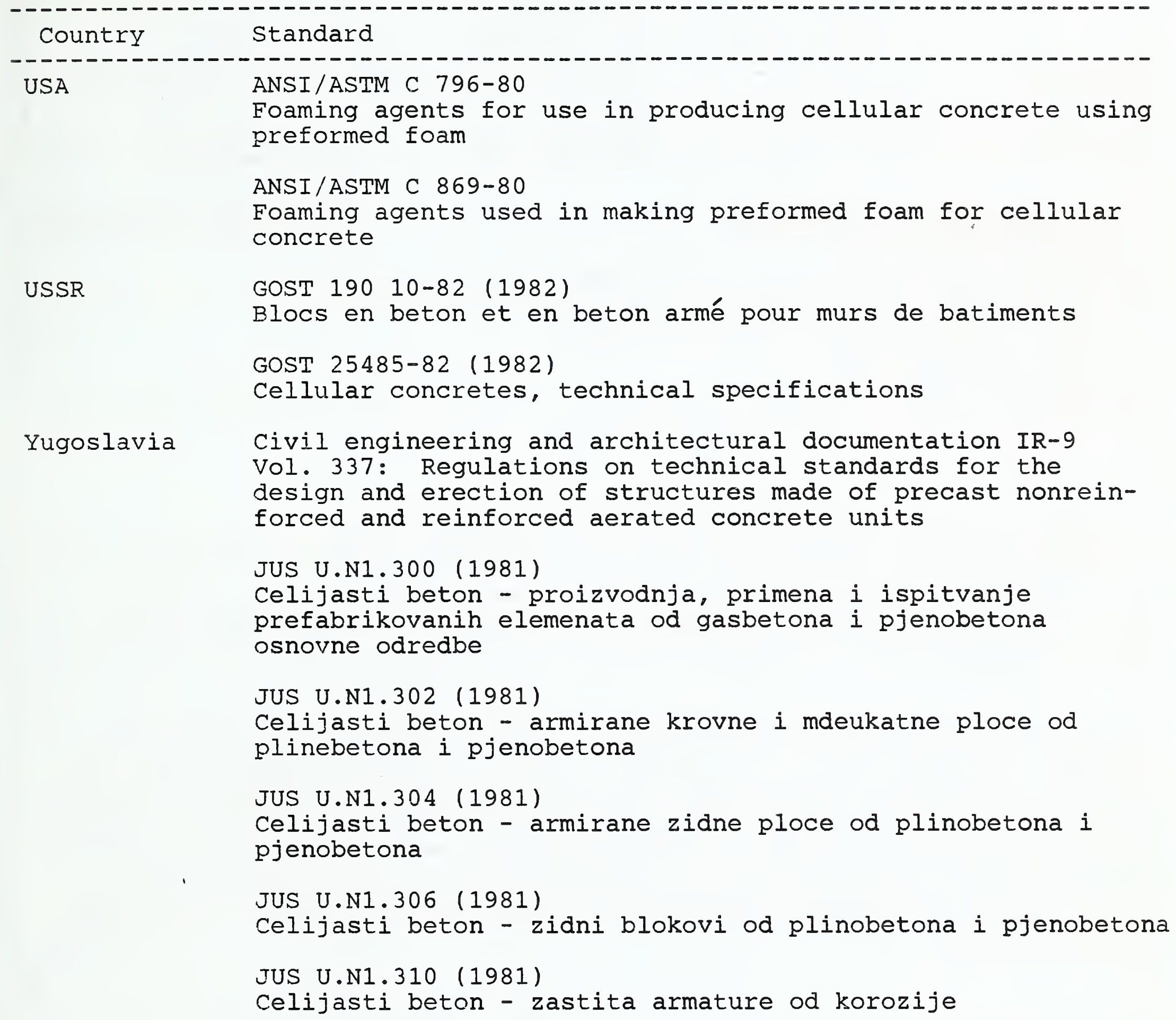


NBS-114A (REV. 2-8O)

U.S. DEPT. OF COMM.

1. PUBLICATION OR

2. Performing Organ. Report Nof 3. Publication Date

BIBLIOGRAPHIC DATA REPORT NO.

SHEET (See in structions)

NBSIR $87-3670$

MARCH 1988

4. TITLE AND SUBTITLE

A Review of Autoclaved Aerated Concrete Products

5. AUTHOR(S)

Robert G. Mathey and Walter J. Rossiter, Jr.

6. PERFORMING ORGANIZATION (If joint or other than NBS, see instructions)

7. Contract/Grant No.

NATIONAL BUREAU OF STANDARDS

U.S. DEPARTMENT OF COMMERCE

GAITHERSBURG, MD 20899

9. SPONSORING ORGANIZATION NAME AND COMPLETE ADDRESS (Street, City. State, ZIP)

U.S. Department of Energy

Office of Conservation and Renewable Energy

1000 Independence Ave., SW

Washington, DC 20585

10. SUPPLEMENTARY NOTES

[Docüment describes a computer program; SF-185, FIPS Software Summary, is attached.

11. ABSTRACT (A 200-word or less factual summary of most significant information. If document includes a significant bibliography or literature survey. mention it here)

This report is a review of the properties and performance of autoclaved aerated concrete. The material has a relatively low thermal conductivity combined with loadbearing capacity for use in structural and non-structural applications. This feature may make its use attractive for energy-conserving applications. For this reason, the review was conducted at the request of the U.S. Department of Energy.

The review addressed an overview of the manufacturing process, uses of autoclaved aerated concrete in bijlding constructions, properties, energy considerations, the availability of code-related documents, and standards. Uses include block and panel construction in both loadbearing and non-loadbearing applications for walls, floors, and roofs. Many properties are reviewed including density, fire resistance, moisture expansion and shrinkage, strength, structure, and thermal conductivity. With regard to energy considerations the review points out that, for energy-efficient applications under severe climatic conditions, the autoclaved aerated concrete unit alone may be insufficient to provide the targeted minimum value of thermal resistance. In these cases, autoclaved aerated concrete has to be used together with additional thermal insulation. In contrast, autoclaved aerated concrete alone may satisfy insulation needs in areas having mild climates.

12. KEY WORDS (Six to tweive entries; aiphabetical order; capitalize oniy proper names; and separate key words by semicolons) aerated; autoclaved; cellular; concrete; insulating concrete; 1ightweight; manufacture; properties; standards; uses.

13. AVAILABILITY

[X] Unlimited

For Official Distribution. Do Not Release to NTIS

Order From Superintendent of Documents, U.S. Government Printing Office, Washington, D.C. 20402.

[X] Order From National Technical Information Service (NTIS), Springfield, VA. 22161
14. NO. OF

PRINTED PAGES

79

15. Price

$\$ 13.95$ 
